Article

\title{
Organ-Specific Metabolic Shifts of Flavonoids in Scutellaria baicalensis at Different Growth and Development Stages
}

\author{
Jingyuan Xu ${ }^{\circledR}$, Yilan Yu, Ruoyun Shi, Guoyong Xie, Yan Zhu, Gang Wu and Minjian Qin * (10 \\ Department of Resources Science of Traditional Chinese Medicines, School of Traditional Chinese Pharmacy \\ and State Key Laboratory of Natural Medicines, China Pharmaceutical University, Nanjing 210009, China; \\ Xujingyuanxu@126.com (J.X.); 15250962227@163.com (Y.Y.); spajk3245@126.com (R.S.); \\ guoyongxie321@163.com (G.X.); cpuzy@126.com (Y.Z.); woosmail@163.com (G.W.) \\ * Correspondence: qmj@cpu.edu.cn; Tel.: +86-025-8618-5130
}

Received: 24 January 2018; Accepted: 14 February 2018; Published: 15 February 2018

\begin{abstract}
Scutellaria baicalensis Georgi is a traditional Chinese herbal medicine mainly containing flavonoids that contribute to its bioactivities. In this study, the distributions and dynamic changes of flavonoid levels in various organs of $S$. baicalensis at different development stages were investigated by UHPLC-QTOF-MS/MS and HPLC-DAD methods. The results indicated that the metabolic profiles of S. baicalensis changed with growth and development. During the initial germination stage, the seeds mainly contained flavonols. With growth, the main kinds of flavonoids in S. baicalensis changed from flavonols to flavanones and flavones. The results also revealed that the accumulation of flavonoids in S. baicalensis is organ-specific. The flavones without $4^{\prime}-\mathrm{OH}$ groups mainly accumulate in the root and the flavanones mainly accumulate in aerial organs. Dynamic accumulation analysis showed that the main flavonoids in the root of $S$. baicalensis accumulated rapidly before the full-bloom stage, then changed to a small extent. The results suggested the proper harvest time for the aerial parts was at the initial stage of reproductive growth and the flower buds should be collected before flowering. This study deepening the knowledge of $S$. baicalensis should provide valuable information for guiding the scientific cultivation of this plant and the development and utilization of S. baicalensis.
\end{abstract}

Keywords: Scutellaria baicalensis; dynamic accumulation; organ-specific; growth; metabolic profile

\section{Introduction}

Scutellaria baicalensis Georgi is a medicinal plant of the Lamiaceae family. Its roots have been used as a traditional Chinese medicine (known as Huang Qin in Chinese), for the treatment of many diseases such as influenza, pneumonia, and dysentery [1,2] for over 2000 years. Many studies have demonstrated that Huang Qin possesses a wide range of pharmacological effects, including antitumor, hepatoprotective and antibacterial effect [3-5]. It is believed that flavones, such as baicalin, wogonoside and their corresponding aglycones baicalein and wogonin are the major bioactive substances responsible for its reliable and efficacious biological activities [6].

On account of its important medicinal value, the annual demand for S. baicalensis is increasing year by year. The yield of $S$. baicalensis based on wild sources is nowadays insufficient and it is gradually being replaced by artificially cultivated plants. As the aerial parts (including the stem, leaf and flower) of $S$. baicalensis are not the traditional medicinal parts, they are usually discarded as waste during the root harvesting or only used as a functional food in limited areas [7], which results in a significant waste of resources. In recently years, researches on the aerial parts of S. baicalensis have attracted more and more attentions. Modern pharmacological studies have shown that the aerial parts of S. baicalensis also have biological activities, such as antiviral [8], anti-lipid peroxidation [9], neuroprotective [10] and 
cardiocyte protective activity [11]. The main bioactive constituents in the aerial parts of $S$. baicalensis are also flavonoids [7,12], such as scutellarin [13], apigenin-7-O- $\beta$-D-glucuronide [14] and baicalin. Therefore, it is worthwhile to exploit the aerial parts of $S$. baicalensis.

Until now, the identifications of flavonoids in S. baicalensis have been reported by several research groups $[6,12,15]$. However, there is no report about the metabolic profiles of all the growth and development stages in the whole life cycle of $S$. baicalensis. The dynamic changes of flavonoid levels in various organs of $S$. baicalensis at different growth and development stages remain unknown. During the plant growth and development, tissue specialization is never an independent event. It is an intricate biological process where differentiation at the physical, chemical, and biological levels, takes place simultaneously [16]. These changes result in a series of dynamic modifications to the whole metabolic pathway network. Understanding these changes could help us to determine the possible physiological effects of metabolites in the plant and guide us to cultivate and utilize the medicinal plant resource in a reasonable manner.

In the present study, the metabolic profiles of S. baicalensis from seed germination to the reproductive growth stage were analyzed by ultra-high-performance liquid chromatography coupled to quadrupole-time of flight mass spectrometry (UHPLC-QTOF-MS/MS). The contents of the main flavonoids in different organs of $S$. baicalensis collected at different growth and development stages were further quantitatively analyzed. This work provides whole metabolic profiles for the complete life cycle of $S$. baicalensis. Meanwhile, the accumulation patterns of main flavonoids in the different organs of $S$. baicalensis at different development periods were also studied. This could effectively promote understanding of how the flavonoid metabolism in S. baicalensis changes and provide us valuable information for the scientific cultivation and optimum harvesting of S. baicalensis.

\section{Results and Discussion}

\subsection{The Metabolic Profiles of S. baicalensis Were Organ-Specific and Changed at Different Growth and Development Stages}

Previous studies showed that S. baicalensis contained a large number of flavonoids [2], but it was not clear how the metabolic profiles of $S$. baicalensis changed at different growth and development stages. To reveal the dynamic changes of metabolic profiles in various organs of $S$. baicalensis at different growth and development stages, samples were collected from the beginning of seed sowing to fruiting (Figure 1).

According to the phenotypic difference, the samples were divided into three stages which were the seed germination stage (from day 0 to day 8 ), seedling stage (from day 10 to day 22) and plant maturity stage (day 62 and day 83), respectively. The collected samples were analyzed by UHPLC-QTOF-MS/MS. A total of 98 different compounds were characterized in 27 different samples (Table 1). The identified compounds were mainly flavonoids, while some other compounds classes such as phenylpropanoid glycosides, phenolic acids and quinones were also authenticated in S. baicalensis (Figure S1). 
Table 1. Compounds identified by UHPLC-QTOF-MS/MS in S. baicalensis collected at different growth stages.

\begin{tabular}{|c|c|c|c|c|c|c|c|}
\hline No. & $t_{R}(\min )$ & $\begin{array}{l}\text { Molecular } \\
\text { Formula }\end{array}$ & $\begin{array}{l}{[\mathrm{M}-\mathrm{H}]^{-}} \\
\text {Predicted }\end{array}$ & $\begin{array}{l}{\left[\mathbf{M}-\mathbf{H}^{-}\right.} \\
\text {Measured }\end{array}$ & $\begin{array}{l}\text { Error } \\
(\mathrm{ppm})\end{array}$ & (-)-ESI-MS/MS Fragment Ions $(m / z)$ & Identification [Reference] \\
\hline 1 & 1.59 & $\mathrm{C}_{21} \mathrm{H}_{22} \mathrm{O}_{13}$ & 481.09876 & 481.09832 & -0.9 & $\begin{array}{l}463.0880,319.0452,301.0345,257.0457,233.0465 \\
215.0337,193.0141,175.0039,151.0043,125.0254\end{array}$ & Dihydromyricetin-3'-O-glucoside [17] \\
\hline 2 & 2.24 & $\mathrm{C}_{21} \mathrm{H}_{22} \mathrm{O}_{13}$ & 481.09876 & 481.09866 & -0.2 & $\begin{array}{c}301.0349,257.0448,215.0344,193.0142,175.0045 \\
151.0045,125.0254,137.0251\end{array}$ & Isomer of dihydromyricetin-3'-O-glucoside \\
\hline 3 & 2.43 & $\mathrm{C}_{21} \mathrm{H}_{22} \mathrm{O}_{12}$ & 465.10385 & 465.10158 & -4.9 & $\begin{array}{c}303.0398,285.0396,273.0295,241.0461,219.0260 \\
177.0181,125.0267\end{array}$ & Taxifolin-7-O-glucoside [18] \\
\hline 4 & 3.5 & $\mathrm{C}_{21} \mathrm{H}_{22} \mathrm{O}_{12}$ & 465.10385 & 465.10313 & -1.6 & $\begin{array}{c}303.0505,285.0398,275.0551,259.0600,241.0511 \\
217.0509,125.0254\end{array}$ & Isomer of Taxifolin-7-O-glucoside \\
\hline 5 & 4.43 & $\mathrm{C}_{21} \mathrm{H}_{22} \mathrm{O}_{12}$ & 465.10385 & 465.10323 & -1.3 & $\begin{array}{c}\text { 303.0504, 285.0388, 241.0522, } 199.0364,179.0001 \\
149.0248,125.0243\end{array}$ & Isomer of Taxifolin-7-O-glucoside \\
\hline 6 & 4.84 & $\mathrm{C}_{15} \mathrm{H}_{12} \mathrm{O}_{9}$ & 335.04086 & 335.04074 & -0.4 & $183.0294,169.0135,139.0404,125.0252,115.0405$ & Methyl digallate [19] \\
\hline 7 & 5.27 & $\mathrm{C}_{21} \mathrm{H}_{22} \mathrm{O}_{13}$ & 481.09876 & 481.09846 & -0.6 & $\begin{array}{l}463.0893,301.0352,283.0247,257.0551,255.0291 \\
215.03 .52,193.0142,162.0359,153.0198,125.0253\end{array}$ & Isomer of dihydromyricetin-3'-O-glucoside \\
\hline 8 & 5.69 & $\mathrm{C}_{22} \mathrm{H}_{24} \mathrm{O}_{12}$ & 479.11950 & 479.11847 & -2.2 & $317.0648,285.0444,165.0204$ & $\begin{array}{l}\text { 3,5,7,4'-Tetrahydroxy-6-methoxy Flavanone } \\
\text { 3-O- } \beta \text {-D-glucoside }\end{array}$ \\
\hline 9 & 7.75 & $\mathrm{C}_{15} \mathrm{H}_{12} \mathrm{O}_{8}$ & 319.04594 & 319.04568 & -0.8 & $\begin{array}{c}233.0475,215.0341,193.0138,175.0034,165.0189 \\
151.0037,137.0246,125.0253\end{array}$ & Dihydromyricetin [20] \\
\hline 10 & 8.40 & $\mathrm{C}_{21} \mathrm{H}_{20} \mathrm{O}_{13}$ & 479.08311 & 479.08288 & -0.5 & $\begin{array}{c}317.0294,289.0319,287.0181,243.0296,178.9981 \\
151.0033,137.0250\end{array}$ & Myricetin-3-O-Galactoside [21] \\
\hline 11 & 8.74 & $\mathrm{C}_{21} \mathrm{H}_{20} \mathrm{O}_{11}$ & 447.09329 & 447.09334 & 0.1 & $285.0460,217.0147,151.0035$ & $\begin{array}{c}5,7,2^{\prime}, 6^{\prime} \text {-Tetrahydroxy Flavone } \\
2^{\prime}-O-\beta \text {-D-glucoside }[6]\end{array}$ \\
\hline 12 & 9.05 & $\mathrm{C}_{15} \mathrm{H}_{12} \mathrm{O}_{7}$ & 303.05103 & 303.05052 & -1.7 & $125.0256,149.0231,177.0176,267.0288$ & $3,5,7,2^{\prime}, 6^{\prime}$-Pentahydroxy Flavanone [6] \\
\hline 13 & 9.17 & $\mathrm{C}_{21} \mathrm{H}_{22} \mathrm{O}_{12}$ & 465.10385 & 465.10367 & -0.4 & $\begin{array}{c}\text { 303.0505, 285.0408, 275.0556, 259.0609, 241.0498, } \\
217.0511,199.0389,177.0196,125.0250\end{array}$ & Isomer of Taxifolin-7-O-glucoside \\
\hline 14 & 9.4 & $\mathrm{C}_{15} \mathrm{H}_{12} \mathrm{O}_{8}$ & 319.04594 & 319.04571 & -0.7 & $\begin{array}{c}215.0349,193.0139,175.0037,165.0189,151.0039 \\
137.0249,125.0249\end{array}$ & Isomer of dihydromyricetin \\
\hline 15 & 9.63 & $\mathrm{C}_{27} \mathrm{H}_{30} \mathrm{O}_{17}$ & 625.14102 & 625.14242 & 2.2 & $\begin{array}{c}463.0871,300.0274,271.0245,255.0309 \\
243.0309,178.9969\end{array}$ & $\begin{array}{l}\text { Quercetin-4'-O- } \beta \text {-D-glucopyranosyl-( }(1 \rightarrow 2)-\beta \text {-D- } \\
\text { glucopyranoside [22] }\end{array}$ \\
\hline
\end{tabular}


Table 1. Cont

\begin{tabular}{|c|c|c|c|c|c|c|c|}
\hline No. & $t_{R}(\min )$ & $\begin{array}{l}\text { Molecular } \\
\text { Formula }\end{array}$ & $\begin{array}{l}{[\mathrm{M}-\mathrm{H}]^{-}} \\
\text {Predicted }\end{array}$ & $\begin{array}{l}{[\mathrm{M}-\mathrm{H}]^{-}} \\
\text {Measured }\end{array}$ & $\begin{array}{l}\text { Error } \\
(\mathrm{ppm})\end{array}$ & (-)-ESI-MS/MS Fragment Ions $(m / z)$ & Identification [Reference] \\
\hline 16 & 9.67 & $\mathrm{C}_{21} \mathrm{H}_{20} \mathrm{O}_{13}$ & 479.08311 & 479.08305 & -0.1 & $\begin{array}{c}303.0506,285.0384,181.0138,166.9992 \\
135.0463,113.0277\end{array}$ & $\begin{array}{c}\text { 5,6,7,3', } 4^{\prime} \text {-Pentahydroxy Flavanon } \\
\text { 7-O- } \beta \text {-D-glucoronide [12] }\end{array}$ \\
\hline 17 & 9.88 & $\mathrm{C}_{26} \mathrm{H}_{28} \mathrm{O}_{14}$ & 563.14063 & 563.13869 & -3.4 & $503.1135,473.1102,443.1020,383.0779,353.0672$ & Schaftoside [15] \\
\hline 18 & 9.92 & $\mathrm{C}_{26} \mathrm{H}_{28} \mathrm{O}_{14}$ & 563.14063 & 563.14154 & 1.6 & $503.1244,473.1127,443.0978,383.0791,353.0662$ & Isoschaftoside [15] \\
\hline 19 & 9.98 & $\mathrm{C}_{21} \mathrm{H}_{20} \mathrm{O}_{11}$ & 447.09329 & 447.09289 & -0.9 & $285.0403,284.0319,240.0448,227.0302,228.0412$ & Kaempferol-3-O-glucoside [23] \\
\hline 20 & 10.29 & $\mathrm{C}_{21} \mathrm{H}_{22} \mathrm{O}_{11}$ & 449.10894 & 449.10785 & -2.4 & $\begin{array}{c}125.0252,151.0029,161.0244,177.0204,227.0360 \\
269.0466,287.0558\end{array}$ & $\begin{array}{c}5,7,2^{\prime}, 6^{\prime} \text {-TetrahydroxyFlavanone } \\
2^{\prime} \text {-O- } \beta \text {-D-glucoside [6] }\end{array}$ \\
\hline 21 & 10.46 & $\mathrm{C}_{22} \mathrm{H}_{22} \mathrm{O}_{12}$ & 477.10385 & 477.10258 & -2.7 & $301.0349,283.0264,164.9816$ & 6-Hydroxyluteolin 7-O- $\beta$-D-glucoronide [6] \\
\hline 22 & 11.04 & $\mathrm{C}_{21} \mathrm{H}_{22} \mathrm{O}_{12}$ & 465.10385 & 465.10384 & 0 & $303.0872,285.0765,259.0977,244.0734,137.0611$ & Isomer of Taxifolin-7-O-glucoside \\
\hline 23 & 11.16 & $\mathrm{C}_{27} \mathrm{H}_{30} \mathrm{O}_{16}$ & 609.14611 & 609.14694 & 1.4 & $\begin{array}{c}\text { 489.1024, 447.0911, 429.0817, 284.0321, 255.0295, } \\
\text { 227.0340, 211.0394, 178.9980, 151.0031 }\end{array}$ & Unknown \\
\hline 24 & 12.13 & $\mathrm{C}_{26} \mathrm{H}_{28} \mathrm{O}_{13}$ & 547.14571 & 547.14391 & -3.3 & $487.1257,457.1136,427.1046,367.0819,337.0717$ & Chrysin 6-C-arabinoside-8-C-glucoside [7] \\
\hline 25 & 12.66 & $\mathrm{C}_{21} \mathrm{H}_{20} \mathrm{O}_{12}$ & 463.08820 & 463.08660 & -3.5 & $\begin{array}{c}287.0560,269.0541,259.0602,181.0142,166.9993 \\
153.0201,119.0517\end{array}$ & Isocarthamidin -7-O- $\beta$-D-glucuronide [24] \\
\hline 26 & 12.91 & $\mathrm{C}_{21} \mathrm{H}_{18} \mathrm{O}_{12}$ & 461.07255 & 461.07073 & -3.9 & $285.0395,257.0435,164.9827,136.9883,119.0517$ & Luteolin 7-O-glucuronide [25] \\
\hline 27 & 13.27 & $\mathrm{C}_{21} \mathrm{H}_{20} \mathrm{O}_{11}$ & 447.09329 & 447.09284 & -1 & $285.0390,284.0314,271.0611,256.0293$ & Isomer of Kaempferol-3-O-glucoside \\
\hline 28 & 13.47 & $\mathrm{C}_{23} \mathrm{H}_{24} \mathrm{O}_{13}$ & 507.11441 & 507.11317 & -2.4 & $345.0617,330.0379,315.0150$ & Viscidulin III 6'-O- $\beta$-D-glucoside [6] \\
\hline 29 & 13.59 & $\mathrm{C}_{21} \mathrm{H}_{18} \mathrm{O}_{12}$ & 461.07255 & 461.07162 & -2.0 & $285.0401,267.0292,239.0363,213.0548,195.0455$ & Scutellarin [24] \\
\hline 30 & 14.00 & $\mathrm{C}_{29} \mathrm{H}_{36} \mathrm{O}_{15}$ & 623.19814 & 623.19657 & -2.5 & $461.1696,161.0239$ & Acteoside [6] \\
\hline 31 & 14.13 & $\mathrm{C}_{26} \mathrm{H}_{28} \mathrm{O}_{13}$ & 547.14571 & 547.14518 & -1.0 & $457.1140,427.1040,367.0822,337.0720$ & Chrysin 6-C-glucoside-8-C-arabinoside [15] \\
\hline 32 & 14.84 & $\mathrm{C}_{21} \mathrm{H}_{20} \mathrm{O}_{12}$ & 463.08820 & 463.08735 & -1.8 & $\begin{array}{c}287.0542,269.0453,259.0616,193.0147,181.0147 \\
166.0021,153.0203,119.0520\end{array}$ & carthamidin -7-O- $\beta$-D-glucuronide [24] \\
\hline 33 & 15.55 & $\mathrm{C}_{23} \mathrm{H}_{24} \mathrm{O}_{12}$ & 491.11950 & 491.11730 & -4.5 & $329.0659,314.0432,299.0189$ & $\begin{array}{c}5,2^{\prime}, 6^{\prime} \text {-Dihydroxy-7,8-dimethoxy Flavone } \\
2^{\prime} \text {-O- } \beta \text {-D-glucoside [6] }\end{array}$ \\
\hline 34 & 17.07 & $\mathrm{C}_{21} \mathrm{H}_{18} \mathrm{O}_{12}$ & 461.07255 & 461.07033 & -4.8 & $\begin{array}{c}285.0408,257.0463,229.0451,241.0514,213.0581, \\
199.0387,185.0590,113.0268\end{array}$ & Kaempferol-3-O- $\beta$-D-glucuronide [26] \\
\hline
\end{tabular}


Table 1. Cont

\begin{tabular}{|c|c|c|c|c|c|c|c|}
\hline No. & $t_{R}(\min )$ & $\begin{array}{l}\text { Molecular } \\
\text { Formula }\end{array}$ & $\begin{array}{c}{[\mathrm{M}-\mathrm{H}]^{-}} \\
\text {Predicted }\end{array}$ & $\begin{array}{l}{\left[\mathrm{M}-\mathrm{H}^{-}\right.} \\
\text {Measured }\end{array}$ & $\begin{array}{l}\text { Error } \\
(\text { ppm) }\end{array}$ & (-)-ESI-MS/MS Fragment Ions $(m / z)$ & Identification [Reference] \\
\hline 35 & 17.17 & $\mathrm{C}_{21} \mathrm{H}_{20} \mathrm{O}_{9}$ & 415.10346 & 415.10199 & -3.5 & $325.0714,295.0610,267.0661$ & Chrysin 8-C- $\beta$-D-glucoside [6] \\
\hline 36 & 17.25 & $\mathrm{C}_{21} \mathrm{H}_{20} \mathrm{O}_{10}$ & 431.09837 & 431.09691 & -3.4 & 269.0447 & Apigenin-7-O- $\beta$-D-glucoside [25] \\
\hline 37 & 17.43 & $\mathrm{C}_{22} \mathrm{H}_{20} \mathrm{O}_{12}$ & 475.08820 & 475.08685 & -2.8 & $299.0549,271.0641,256.0365,227.0761,165.0218$ & $\begin{array}{l}\text { 5,6,7-Trihydroxy-8-methoxy-7-O- } \beta \text {-D-glucuronide } \\
\text { [27] }\end{array}$ \\
\hline 38 & 17.53 & $\mathrm{C}_{21} \mathrm{H}_{20} \mathrm{O}_{11}$ & 447.09329 & 447.09216 & -2.5 & $\begin{array}{c}285.0393,284.0321,269.0411,257.0456,255.0291 \\
227.0324,213.0568,151.0042,107.0157\end{array}$ & Isomer of Kaempferol-3-O-glucoside \\
\hline 39 & 17.64 & $\mathrm{C}_{24} \mathrm{H}_{26} \mathrm{O}_{13}$ & 521.13006 & 521.12836 & -3.3 & $359.0769,344.0544,329.0311,314.0057$ & $\begin{array}{l}5,2^{\prime}, 6^{\prime} \text {-Trihydroxy-6,7,8,-trimethoxy Flavone } \\
2^{\prime} \text {-O- } \beta \text {-D-glucoside [2] }\end{array}$ \\
\hline 40 & 17.79 & $\mathrm{C}_{15} \mathrm{H}_{10} \mathrm{O}_{6}$ & 285.04046 & 285.04014 & -1.1 & $199.0388,151.0054$ & 5,7,2',6'-Tetrahydroxy Flavone [6] \\
\hline 41 & 17.90 & $\mathrm{C}_{15} \mathrm{H}_{12} \mathrm{O}_{6}$ & 287.05611 & 287.05510 & -3.5 & $259.0661,177.0546,125.0245$ & Carthamidin [25] \\
\hline 42 & 17.98 & $\mathrm{C}_{21} \mathrm{H}_{18} \mathrm{O}_{11}$ & 445.07764 & 445.07600 & -3.7 & $269.0462,225.0563,113.0261$ & Apigenin-7-O- $\beta$-D-glucuronide [12] \\
\hline 43 & 18.07 & $\mathrm{C}_{21} \mathrm{H}_{20} \mathrm{O}_{11}$ & 447.09239 & 447.09218 & -2.5 & $\begin{array}{c}271.0604,177.0223,151.0043,119.0516 \\
113.0261,107.0160\end{array}$ & Naringenin-7-O- $\beta$-D-glucuronide [7] \\
\hline 44 & 18.29 & $\mathrm{C}_{21} \mathrm{H}_{20} \mathrm{O}_{12}$ & 463.08820 & 463.08743 & -1.7 & $\begin{array}{c}287.0570,269.0420,259.0658,193.0149,181.0149 \\
166.9982,153.0196,139.0041,119.0531\end{array}$ & Eriodictyol-7-O- $\beta$-D-glucuronide [25] \\
\hline 45 & 18.38 & $\mathrm{C}_{15} \mathrm{H}_{12} \mathrm{O}_{6}$ & 287.05611 & 287.05516 & -3.3 & $\begin{array}{c}181.0142,153.0188,166.9973,139.0038 \\
136.9891,119.0497\end{array}$ & Isocarthamidin [28] \\
\hline 46 & 18.59 & $\mathrm{C}_{15} \mathrm{H}_{10} \mathrm{O}_{8}$ & 317.03029 & 317.02999 & -1 & $\begin{array}{c}\text { 289.0304, 271.0231, 261.0358, 243.0274, 227.0334, } \\
\begin{array}{c}193.0143,178.9985,165.0192,151.0044,137.0254, \\
125.0246,109.0310,107.0148\end{array}\end{array}$ & Myricetin [29] \\
\hline 47 & 18.64 & $\mathrm{C}_{22} \mathrm{H}_{20} \mathrm{O}_{12}$ & 475.08820 & 475.08692 & -2.7 & $299.0560,284.0314$ & $\begin{array}{l}\text { 5,7,8-Trihydroxy-6-methoxy } \\
\text { Flavone-7-O- } \beta \text {-D-glucuronide [30] }\end{array}$ \\
\hline 48 & 18.68 & $\mathrm{C}_{21} \mathrm{H}_{18} \mathrm{O}_{12}$ & 461.07255 & 461.07194 & -1.3 & $\begin{array}{c}285.0353,139.0017,257.0466,164.9834 \\
136.9886,119.0510\end{array}$ & Isoscutellarein 8-O- $\beta$-D-glucuronide [12] \\
\hline 49 & 18.98 & $\mathrm{C}_{22} \mathrm{H}_{22} \mathrm{O}_{12}$ & 477.10385 & 477.10144 & -5.0 & $331.0311,301.0334,180.9795,155.0067,119.0530$ & $\begin{array}{c}\text { 5,7,2'-Trihydroxy-6-methoxy Flavanone } \\
\text { 7-O- } \beta \text {-D-glucuronoide [15] }\end{array}$ \\
\hline 50 & 19.01 & $\mathrm{C}_{22} \mathrm{H}_{22} \mathrm{O}_{12}$ & 477.10385 & 477.10234 & -3.2 & $301.0697,286.0475,181.0148$ & $\begin{array}{c}\text { 5,7,2'-Trihydroxy-8-methoxyFlavanone } \\
\text { 7-O- } \beta \text {-D-glucuronoide [15] }\end{array}$ \\
\hline
\end{tabular}


Table 1. Cont

\begin{tabular}{|c|c|c|c|c|c|c|c|}
\hline No. & $t_{R}(\min )$ & $\begin{array}{l}\text { Molecular } \\
\text { Formula }\end{array}$ & $\begin{array}{c}{[\mathbf{M}-\mathbf{H}]^{-}} \\
\text {Predicted }\end{array}$ & $\begin{array}{l}{[\mathbf{M}-\mathbf{H}]^{-}} \\
\text {Measured }\end{array}$ & $\begin{array}{l}\text { Error } \\
(\mathrm{ppm})\end{array}$ & (-)-ESI-MS/MS Fragment Ions $(\mathrm{m} / \mathrm{z})$ & Identification [Reference] \\
\hline 51 & 20.28 & $\mathrm{C}_{21} \mathrm{H}_{20} \mathrm{O}_{11}$ & 447.09329 & 447.09211 & -2.6 & $285.0397,267.0289,241.0539,199.0371,151.0062$ & Isomer of Kaempferol-3-O-glucoside \\
\hline 52 & 20.58 & $\mathrm{C}_{16} \mathrm{H}_{14} \mathrm{O}_{7}$ & 315.05103 & 315.05069 & -1.1 & $\begin{array}{c}300.0276,272.0319,244.0378,216.0419,187.0398 \\
180.9781,152.9843,124.9893\end{array}$ & Pedalitin \\
\hline 53 & 20.67 & $\mathrm{C}_{15} \mathrm{H}_{10} \mathrm{O}_{6}$ & 285.04046 & 285.04042 & -0.1 & 239.0327, 167.0010, 137.0260, 117.0353 & Scutellarein [25] \\
\hline 54 & 21.17 & $\mathrm{C}_{23} \mathrm{H}_{24} \mathrm{O}_{12}$ & 491.11950 & 491.11970 & 0.4 & $329.0635,314.0426,299.0252$ & $\begin{array}{c}5,2^{\prime}, 6^{\prime} \text {-Dihydroxy-6,7-dimethoxy Flavone } \\
2^{\prime}-O-\beta \text {-D-glucoside [30] }\end{array}$ \\
\hline 55 & 21.28 & $\mathrm{C}_{21} \mathrm{H}_{20} \mathrm{O}_{10}$ & 431.09837 & 431.09702 & -3.1 & $269.0445,251.0354,195.0465,167.0506$ & Baicalein 7-O- $\beta$-D-glucoside [6] \\
\hline 56 & 21.36 & $\mathrm{C} 21 \mathrm{H} 18 \mathrm{O} 11$ & 445.07764 & 445.07622 & -3.2 & $269.0456,251.0345,223.0397,197.0621,113.0262$ & Baicalin [12] \\
\hline 57 & 21.70 & $\mathrm{C}_{15} \mathrm{H}_{10} \mathrm{O}_{5}$ & 269.04555 & 269.04489 & -2.4 & $\begin{array}{c}251.0376,241.0485,223.0416,195.0458, \\
139.0061,111.0072\end{array}$ & Islandicin \\
\hline 58 & 22.08 & $\mathrm{C}_{15} \mathrm{H}_{10} \mathrm{O}_{6}$ & 285.04046 & 285.03977 & -2.4 & $241.0509,213.0540,195.0482,239.0333$ & Isoscutellarein [26] \\
\hline 59 & 22.68 & $\mathrm{C}_{21} \mathrm{H}_{18} \mathrm{O}_{12}$ & 461.07255 & 461.07031 & -4.9 & $285.0415,267.0285,239.0317$ & Isoscutellarein-7-O- $\beta$-D-glucuronide [12] \\
\hline 60 & 23.50 & $\mathrm{C}_{31} \mathrm{H}_{40} \mathrm{O}_{15}$ & 651.22944 & 651.22685 & -4.0 & $475.1832,193.0499,175.0398,160.0171$ & Cistanoside D [6] \\
\hline 61 & 24.31 & $\mathrm{C}_{22} \mathrm{H}_{20} \mathrm{O}_{12}$ & 475.08820 & 475.08707 & -2.4 & $299.0565,284.0332$ & $\begin{array}{c}\text { 5,7,2'-Trihydroxy-6-methoxy Flavone } \\
\text { 7-O- } \beta \text {-D-glucuronoide [2] }\end{array}$ \\
\hline 62 & 24.37 & $\mathrm{C}_{21} \mathrm{H}_{20} \mathrm{O}_{11}$ & 447.09329 & 447.09150 & -4.0 & $271.0610,243.0652,113.0237$ & Dihydrobaicalin [6] \\
\hline 63 & 24.41 & $\mathrm{C}_{22} \mathrm{H}_{20} \mathrm{O}_{12}$ & 475.08820 & 475.08747 & -1.5 & $\begin{array}{l}460.1019,299.0550,297.0401,284.0195 \\
282.0195,254.0195\end{array}$ & Isomer of cirsimaritin $4^{\prime}$-glucoside \\
\hline 64 & 24.72 & $\mathrm{C}_{16} \mathrm{H}_{14} \mathrm{O}_{6}$ & 301.07176 & 301.07067 & -3.6 & $\begin{array}{c}286.0474,181.0144,165.9916,137.9972 \\
119.0515,110.0026\end{array}$ & 5,7,4'-Trihydroxy-6-methoxy Flavanone [15] \\
\hline 65 & 25.56 & $\mathrm{C}_{21} \mathrm{H}_{18} \mathrm{O}_{11}$ & 445.07764 & 445.07576 & -4.2 & $269.0449,241.0494,225.0556,197.0611,171.0451$ & Norwogonin 7-O- $\beta$-D-glucuronide [6] \\
\hline 66 & 25.86 & $\mathrm{C}_{22} \mathrm{H}_{22} \mathrm{O}_{12}$ & 477.10385 & 477.10214 & -3.6 & $\begin{array}{c}301.0712,283.0620,273.0774,268.0393 \\
139.0037,113.0262\end{array}$ & $\begin{array}{c}5,7,2^{\prime}, 6^{\prime}-\text { Tetrahydroxy flavonol } \\
\text { 7-O- } \beta \text {-D-glucuronoide [26] }\end{array}$ \\
\hline 67 & 26.22 & $\mathrm{C}_{22} \mathrm{H}_{22} \mathrm{O}_{11}$ & 461.10894 & 461.10732 & -3.5 & $299.0536,284.0328,171.0449$ & $\begin{array}{c}\text { 5,7,2'-Trihydroxy-6-methoxy Flavone } \\
\text { 7-O- } \beta \text {-D-glucoside [6] }\end{array}$ \\
\hline 68 & 27.11 & $\mathrm{C}_{21} \mathrm{H}_{18} \mathrm{O}_{11}$ & 445.07764 & 445.07556 & -4.7 & $269.0450,241.0485,225.0560,171.0472$ & Norwogonin 8-O- $\beta$-D-glucuronide [6] \\
\hline 69 & 27.76 & $\mathrm{C}_{21} \mathrm{H}_{18} \mathrm{O}_{10}$ & 429.08272 & 429.08064 & -4.8 & $253.0499,209.0601,143.0503,113.0260$ & Chrysin 7-O- $\beta$-D-glucuronide [24] \\
\hline
\end{tabular}


Table 1. Cont

\begin{tabular}{|c|c|c|c|c|c|c|c|}
\hline No. & $t_{R}(\min )$ & $\begin{array}{l}\text { Molecular } \\
\text { Formula }\end{array}$ & $\begin{array}{l}{[\mathrm{M}-\mathrm{H}]^{-}} \\
\text {Predicted }\end{array}$ & $\begin{array}{l}{[\mathrm{M}-\mathrm{H}]^{-}} \\
\text {Measured }\end{array}$ & $\begin{array}{l}\text { Error } \\
(\mathrm{ppm})\end{array}$ & (-)-ESI-MS/MS Fragment Ions $(m / z)$ & Identification [Reference] \\
\hline 70 & 27.96 & $\mathrm{C}_{22} \mathrm{H}_{20} \mathrm{O}_{11}$ & 459.09329 & 459.09148 & -3.9 & $283.0612,268.0376$ & Oroxylin A 7-O- $\beta$-D-glucuronide [6] \\
\hline 71 & 28.68 & $\mathrm{C}_{22} \mathrm{H}_{20} \mathrm{O}_{12}$ & 475.0882 & 475.08663 & -3.3 & $299.0549,284.0320$ & Isomer of cirsimaritin $4^{\prime}$-glucoside \\
\hline 72 & 28.87 & $\mathrm{C}_{17} \mathrm{H}_{14} \mathrm{O}_{7}$ & 329.06668 & 329.06548 & -3.6 & $314.0451,299.0185,271.0237,164.9808,136.9872$ & 5,2',6'-Trihydroxy-7,8-dimethoxy Flavone [2] \\
\hline 73 & 29.64 & $\mathrm{C}_{16} \mathrm{H}_{14} \mathrm{O}_{6}$ & 301.07176 & 301.07086 & -3.0 & $\begin{array}{c}286.0459,181.0153,165.9924,137.9976 \\
119.0521,110.0027\end{array}$ & 5,7,4'-Trihydroxy-8-methoxy Flavanone [15] \\
\hline 74 & 29.84 & $\mathrm{C}_{21} \mathrm{H}_{18} \mathrm{O}_{11}$ & 445.07764 & 445.07594 & -3.8 & $269.0455,251.0341,223.0383,113.0273$ & Baicalein 6-O- $\beta$-D-glucuronide [6] \\
\hline 75 & 30.6 & $\mathrm{C}_{15} \mathrm{H}_{10} \mathrm{O}_{6}$ & 285.04046 & 285.03945 & -3.6 & $151.0030,107.0150$ & Luteolin [12] \\
\hline 76 & 30.81 & $\mathrm{C}_{22} \mathrm{H}_{20} \mathrm{O}_{11}$ & 459.09329 & 459.09140 & -4.1 & $283.0613,268.0375$ & Wogonoside [12] \\
\hline 77 & 31.34 & $\mathrm{C}_{23} \mathrm{H}_{24} \mathrm{O}_{11}$ & 475.12459 & 475.12307 & -3.2 & $\begin{array}{c}460.0994,445.0748,313.0665,297.0390,283.0199 \\
282.0144,254.0212,226.0276,183.0437\end{array}$ & Cirsimaritin $4^{\prime}$-O-glucoside [31] \\
\hline 78 & 32.05 & $\mathrm{C}_{21} \mathrm{H}_{20} \mathrm{O}_{10}$ & 431.09837 & 431.09633 & -4.7 & $255.0674,213.0562,187.0791,151.0039,113.0259$ & $\begin{array}{c}\text { 5,7-dihydroxy Flavanone } \\
\text { 7-O- } \beta \text {-D-glucuronoide [12] }\end{array}$ \\
\hline 79 & 32.65 & $\mathrm{C}_{23} \mathrm{H}_{22} \mathrm{O}_{12}$ & 489.10385 & 489.10194 & -3.9 & $\begin{array}{c}313.0712,298.0485,283.0243,255.0361 \\
211.0416,113.0274\end{array}$ & $\begin{array}{c}\text { 5,7-Dihydroxy-2',8-dimethoxy Flavone } \\
\text { 7-O- } \beta \text {-D-glucuronide [24] }\end{array}$ \\
\hline 80 & 33.30 & $\mathrm{C}_{18} \mathrm{H}_{16} \mathrm{O}_{8}$ & 359.07724 & 359.07546 & -4.9 & $344.0565,329.0297,314.0125,286.0098,194.9928$ & $5,2^{\prime}, 5^{\prime}$-Trihydroxy-6,7,8-trimethoxy Flavone [2] \\
\hline 81 & 34.84 & $\mathrm{C}_{16} \mathrm{H}_{12} \mathrm{O}_{6}$ & 299.05611 & 299.05566 & -1.5 & $\begin{array}{c}284.0323,255.0232,227.0358,211.0477,183.0436, \\
164.0130,136.9906\end{array}$ & $\begin{array}{c}\text { Isomer of 5,7,4'-Trihydroxy-8-methoxy } \\
\text { Flavone }\end{array}$ \\
\hline 82 & 34.91 & $\mathrm{C}_{15} \mathrm{H}_{10} \mathrm{O}_{5}$ & 269.04555 & 269.04478 & -2.9 & $241.0454,225.0531,195.0443,171.0439,117.0358$ & Apigenin [24] \\
\hline 83 & 36.07 & $\mathrm{C}_{17} \mathrm{H}_{14} \mathrm{O}_{7}$ & 329.06668 & 329.06584 & -2.5 & $\begin{array}{c}314.0461,299.0201,227.0325,165.9927 \\
137.9951,110.0020\end{array}$ & 5,8,2'-Trihydroxy-6,7-dimethoxy Flavone [6] \\
\hline 84 & 36.28 & $\mathrm{C}_{17} \mathrm{H}_{14} \mathrm{O}_{6}$ & 313.07176 & 313.07085 & -2.9 & $\begin{array}{c}298.0542,283.0251,244.8595,211.0396, \\
166.8658,155.0508\end{array}$ & 5,8-Dihydroxy-6,7-dimethoxy Flavone [30] \\
\hline 85 & 36.59 & $\mathrm{C}_{16} \mathrm{H}_{12} \mathrm{O}_{6}$ & 299.05611 & 299.05552 & -2.0 & $\begin{array}{c}284.0318,255.0274,239.0370,171.0454 \\
153.9920,125.9966\end{array}$ & 5,7,4'-Trihydroxy-8-methoxy Flavone [30] \\
\hline 86 & 37.11 & $\mathrm{C}_{18} \mathrm{H}_{16} \mathrm{O}_{7}$ & 343.08233 & 343.08170 & -1.8 & $\begin{array}{c}\text { 328.0591, 313.0331, 298.0112, 270.0167, 241.0502, } \\
226.0271,198.0335,185.0629,155.0521\end{array}$ & SkullcapFlavone I [27] \\
\hline
\end{tabular}


Table 1. Cont

\begin{tabular}{|c|c|c|c|c|c|c|c|}
\hline No. & $t_{R}(\min )$ & $\begin{array}{l}\text { Molecular } \\
\text { Formula }\end{array}$ & $\begin{array}{c}{[\mathbf{M}-\mathbf{H}]^{-}} \\
\text {Predicted }\end{array}$ & $\begin{array}{l}{[\mathbf{M}-\mathbf{H}]^{-}} \\
\text {Measured }\end{array}$ & $\begin{array}{l}\text { Error } \\
(\mathrm{ppm})\end{array}$ & (-)-ESI-MS/MS Fragment Ions $(\mathrm{m} / z)$ & Identification [Reference] \\
\hline 87 & 37.16 & $\mathrm{C}_{15} \mathrm{H}_{10} \mathrm{O}_{5}$ & 269.04555 & 269.04510 & -1.7 & $\begin{array}{c}251.0348,241.0499,223.0399,195.0442 \\
169.0660,136.9880\end{array}$ & Baicalein [6] \\
\hline 88 & 37.54 & $\mathrm{C}_{15} \mathrm{H}_{12} \mathrm{O}_{5}$ & 271.06120 & 271.06073 & -1.7 & $\begin{array}{c}243.0638,225.0535,185.0601,152.0182 \\
139.0070,124.0182\end{array}$ & Dihydronorwogonin [2] \\
\hline 89 & 37.67 & $\mathrm{C}_{17} \mathrm{H}_{14} \mathrm{O}_{7}$ & 329.06668 & 329.06602 & -2.0 & $314.0367,299.0139$ & 5,7,2'-Trihydroxy-8, $6^{\prime}$-dimethoxy Flavone [32] \\
\hline 90 & 38.30 & $\mathrm{C}_{16} \mathrm{H}_{12} \mathrm{O}_{6}$ & 299.05611 & 299.05531 & -2.7 & $284.0312,165.9925$ & 5,6,7-Trihydroxy-4'-methoxy Flavone [33] \\
\hline 91 & 44.26 & $\mathrm{C}_{18} \mathrm{H}_{16} \mathrm{O}_{7}$ & 343.08233 & 343.08158 & -2.2 & $328.0584,313.0347,298.0130,285.0400,164.9831$ & SkullcapFlavone [6] \\
\hline 92 & 44.65 & $\mathrm{C}_{16} \mathrm{H}_{12} \mathrm{O}_{5}$ & 283.06120 & 283.06097 & -0.8 & $\begin{array}{c}268.0371,239.0353,211.0401,184.0532 \\
163.0037,110.0021\end{array}$ & Wogonin [6] \\
\hline 93 & 45.47 & $\mathrm{C}_{15} \mathrm{H}_{10} \mathrm{O}_{4}$ & 253.05063 & 253.05033 & -1.2 & $209.0616,166.8665,143.0516,107.0165$ & Chrysin [24] \\
\hline 94 & 46.31 & $\mathrm{C}_{19} \mathrm{H}_{18} \mathrm{O}_{8}$ & 373.09289 & 373.09147 & -3.8 & $358.0616,343.0434,328.0199,300.0248$ & $\begin{array}{c}5,6^{\prime} \text {-Dihydroxy-6,7,8,2'-tetramethoxy Flavone } \\
{[6]}\end{array}$ \\
\hline 95 & 46.59 & $\mathrm{C}_{16} \mathrm{H}_{12} \mathrm{O}_{5}$ & 283.06120 & 283.06056 & -2.3 & $268.0373,239.0358,211.0363,184.0525,110.0016$ & Oroxylin A [6] \\
\hline 96 & 46.66 & $\mathrm{C}_{15} \mathrm{H}_{12} \mathrm{O}_{4}$ & 255.06628 & 255.06670 & 1.6 & $213.0545,201.8339,182.9022,166.8653$ & Pinocembrin [12] \\
\hline 97 & 47.20 & $\mathrm{C}_{17} \mathrm{H}_{14} \mathrm{O}_{6}$ & 313.07176 & 313.07047 & -4.1 & $298.0505,283.0256,255.0307,183.0454,164.9835$ & 5,7-Dihydroxy-6,8-dimethoxy Flavone [27] \\
\hline 98 & 49.45 & $\mathrm{C}_{18} \mathrm{H}_{16} \mathrm{O}_{7}$ & 343.08233 & 343.08130 & -3.0 & $328.0598,313.0346,298.0124,270.0161$ & Tenaxin I [6] \\
\hline
\end{tabular}




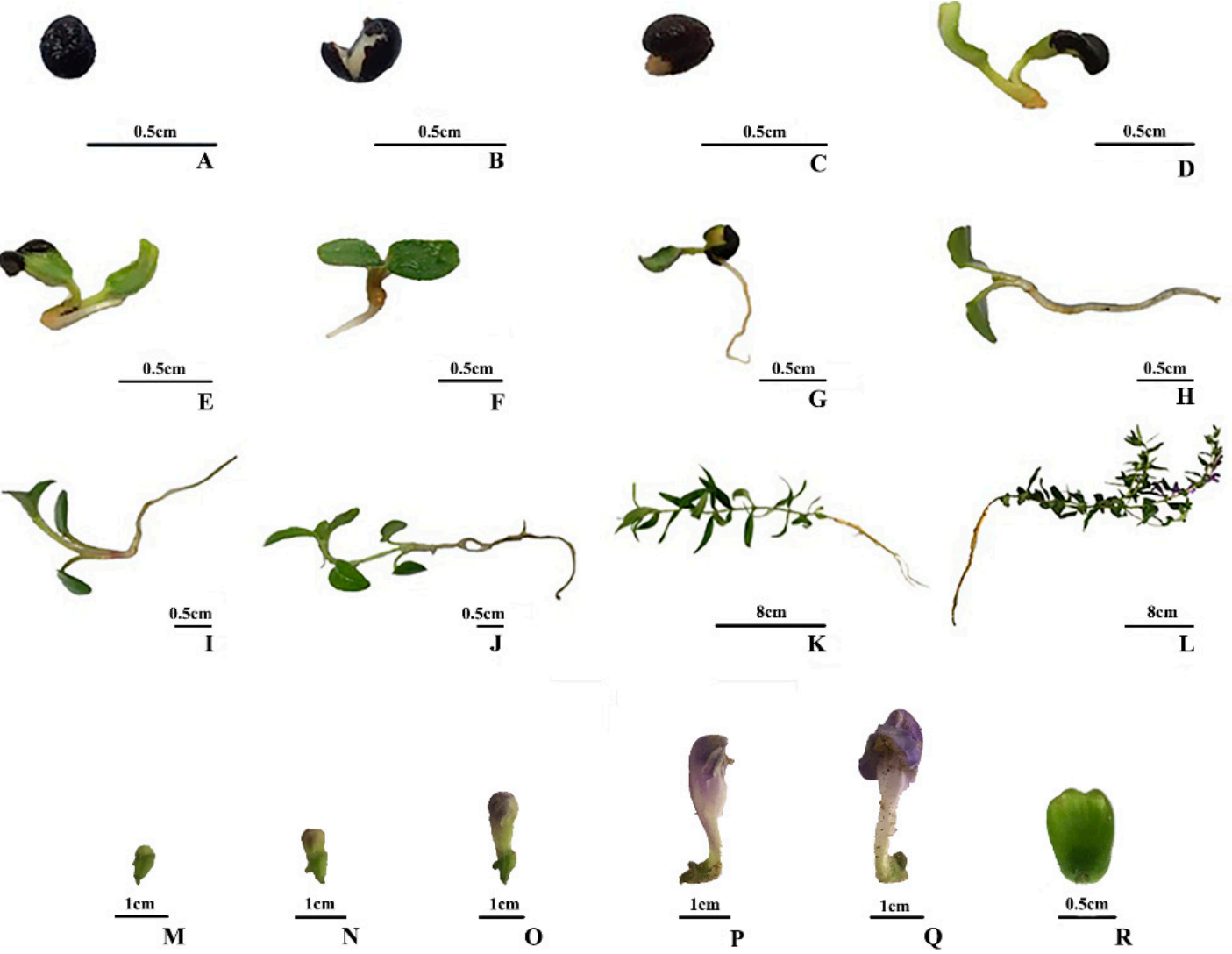

Figure 1. Samples collected at different growth stages. (A): sample collected at the beginning of sowing (day 0); (B): sample collected at the second day (day 2); (C): sample collected at the fourth day (day 4); (D): sample collected at the 6th day (day 6); (E) sample collected at the 8th day (day 8); (F): sample collected at the 10th day (day 10); (G): sample collected at the 12th day (day 12); (H): sample collected at the 14th day (day 14); (I): sample collected at the 18th day (day 18); (J): sample collected at the 22th day (day 22); (K): sample collected at the 62th day (day 62); (L): sample collected at the 83th day (day 83); (M): flower bud 1 (FB1); (N): flower bud 2 (FB2); (O): flower bud 3 (FB3); (P): flower bud 4 (FB4); (Q): flower (FL); (R): fruit (FR).

At the seed germination stage, the main metabolites were flavonols, such as dihydromyricetin$3^{\prime}$-O-glucoside, taxifolin-7-O-glucoside, dihydromyricetin, kaempferol-3-O-glucoside and their isomers. They might mainly exist in the episperm and participate in defending against pathogens and UV-damage [34,35]. With seed germination and seedling growth, the metabolic profiles of S. baicalensis changed. The flavonols did not accumulate with growth, but rather flavones such as scutellarin, baicalin and chrysin-7-O- $\beta$-D-glucuronide began to accumulate. The numbers of identified compounds which were unique in each stage were one for the seed germination stage, eight for the seedling stage and four for the mature plant stage (Figure 2A) and they are listed in Table 2. The results demonstrated that flavonoids were synthesized at each growth stage of $S$. baicalensis, but the metabolic profiles of different development stages obviously differed.

The results of the metabolic analysis also showed that the types of identified compounds in different organs were in the order: reproductive organs $>$ stem $>$ root $>$ leaf. The four parts shared seven common compounds, and the number of unique identified compounds that could only be found in each part were 12 for the roots, two for the stems, one for the leaves and 17 for the reproductive organs (Figure 2B and Table 2). The main type of flavonoids in the root were flavonoids without a $4^{\prime}-\mathrm{OH}$ group, which were significantly different from those with $4^{\prime}-\mathrm{OH}$ in the aerial organs. This might be due to a recently discovered evolved pathway for biosynthesis of specific $4^{\prime}$-deoxyflavones in the roots of 
S. baicalensis [36]. Therefore, the results indicated that in S. baicalensis, the metabolic profiles of different aerial organs were similar and they were different from those of the roots.

A

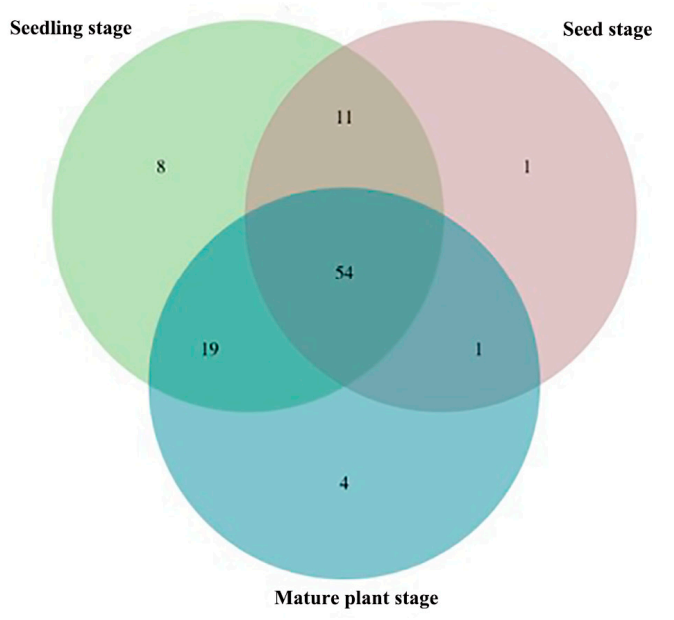

B

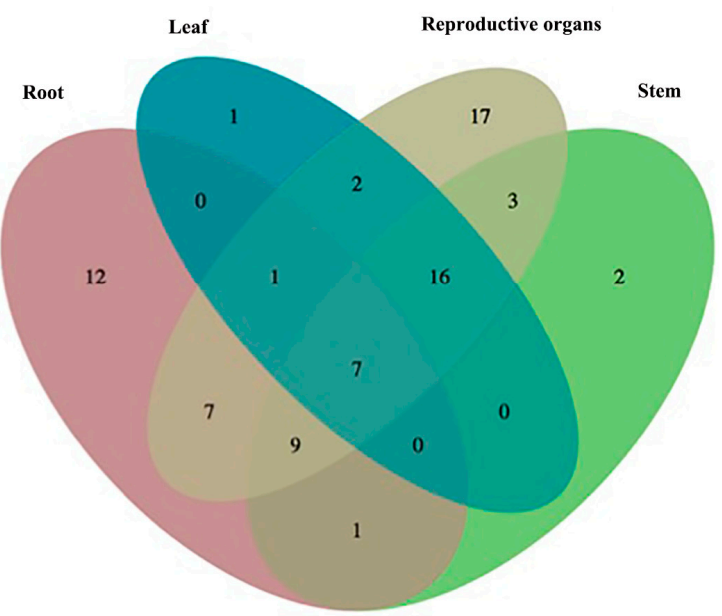

Figure 2. Venn diagrams of identified metabolites in S. baicalensis. (A) was the distribution of unique metabolites and common metabolites in S. baicalensis at seed stage, seedling stage and mature plant stage. (B) was the distributions of unique metabolites and common metabolites in root, leaf, stem and reproductive organs of $S$. baicalensis.

Table 2. The unique compounds identified at different growth stages and in different organs.

\begin{tabular}{|c|c|}
\hline & Number of the Compound \\
\hline \multicolumn{2}{|l|}{ Different growth stage } \\
\hline Seed stage & 83 \\
\hline Seedling stage & $37,59,67,72,75,77,80,97$ \\
\hline Mature stage & $3,8,48,88$ \\
\hline \multicolumn{2}{|l|}{ Different Organ } \\
\hline Root & $11,12,18,28,35,39,70,74,79,85,91,98$ \\
\hline Stem & 60,78 \\
\hline Leaf & 40 \\
\hline Reproductive organs & $2,3,4,6,7,8,10,11,12,14,15,23,36,38,41,46,50,51,96$ \\
\hline
\end{tabular}

According to the distribution of the characterized compounds, the samples could also be divided into different clusters by the unweighted pair-group method with arithmetic (UPGMA) clustering method (Figure 3).

The samples collected at the mature plant stage were distinguished from the samples collected at the seed germination stage and seedling stage. Both the roots of $S$. baicalensis collected at the 62th day (day $62 \mathrm{R}$ ) and the roots of $S$. baicalensis collected at the 83th day (day $83 \mathrm{R}$ ) were clustered into the first branch and significantly separated from other samples. The aerial parts of the samples at mature plant stage were separated into two branches. The reproductive organs collected on the 83th day were clustered into the second branch and the vegetative organs were clustered into the third branch. The fourth branch grouped samples collected from the seed germination stage. The samples collected from the seedling stage were clustered into the fifth branch and they had a huge difference in morphology compared with the samples in the fourth branch. The above results also indicated that the metabolic profiles of $S$. baicalensis were organ-specific and changed with the growth and development phases. 


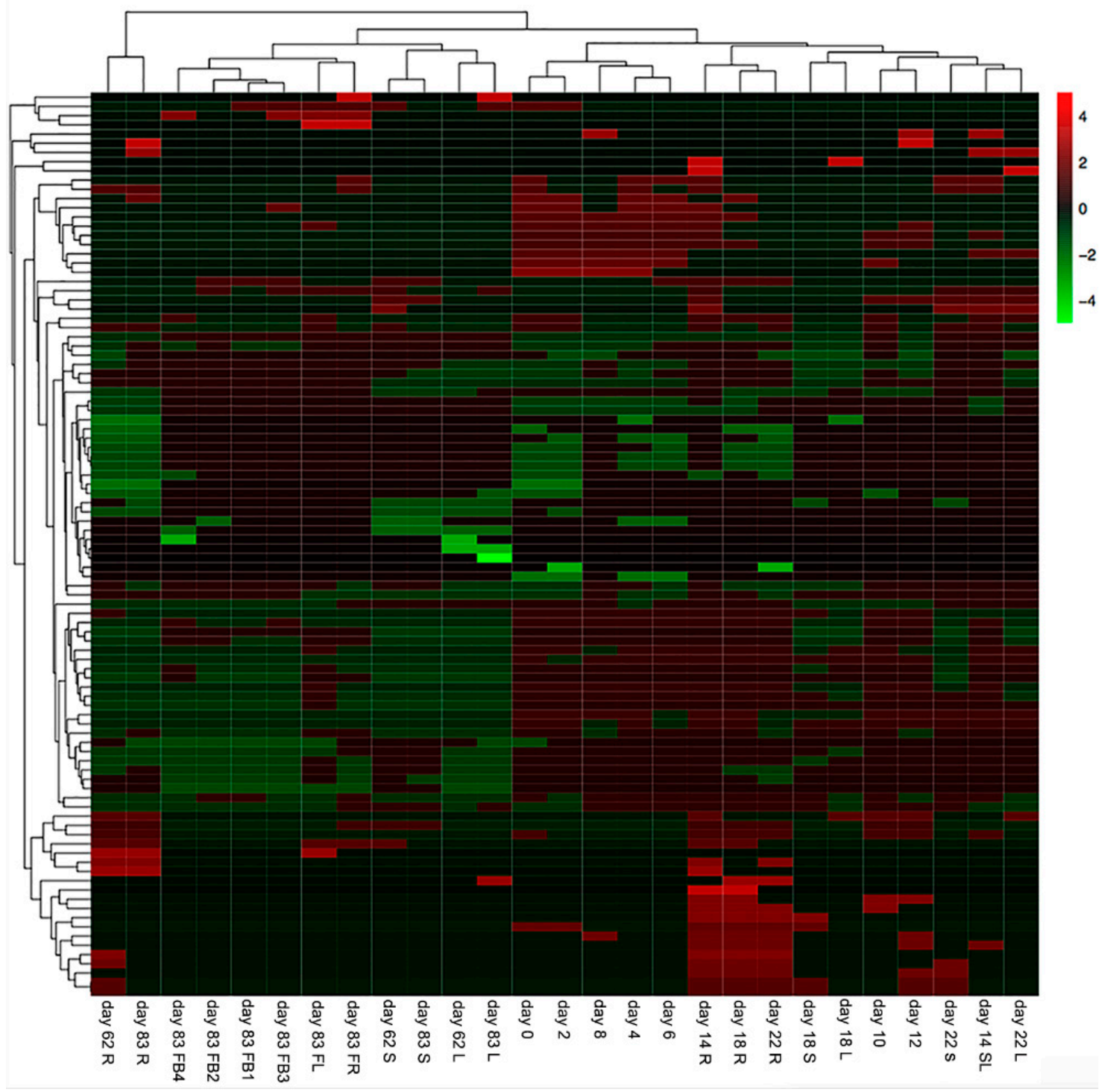

Figure 3. Heat map of the identified metabolites in different organs of S. baicalensis during different growth stages. R: the root of S. baicalensis; S: the stem of S. baicalensis; L: the leaves of S. baicalensis; SL: the leaves and stems of S. baicalensis; FB1 FB4: the flower bud 1 flower bud 4 of S. baicalensis; FL: the flowers of S. baicalensis; Fr: the fruits of S. baicalensis.

\subsection{Dynamic Accumulation of Main Flavonoids in S. baicalensis from Seed Sowing to the True Leaf Coming}

The results of method validation are presented in Table S1. As shown in Figure 4, from the beginning of seed sowing (day 0 ) to the 6th day (day 6), the flavonoids which mainly existed in the mature plant of $S$. baicalensis were too low to be quantified. After the 6 th day of seed sowing, the contents of isocarthamidin-7-O- $\beta$-D-glucuronide, scutellarin, apigenin-7-O- $\beta$-D-glucuronide, baicalin, chrysin-7-O- $\beta$-D-glucuronide and wogonoside gradually increased. By the 14th day, when the true leaves appeared, the samples were separated into two groups, the aerial parts and roots. The contents of baicalin and wogonoside in roots were higher than those in the aerial parts. The contents of isocarthamidin-7-O- $\beta$-D-glucuronide and scutellarin in roots were similar to those in aerial parts. Apigenin-7-O- $\beta$-D-glucuronide and chrysin-7-O- $\beta$-D-glucuronide mainly existed in the aerial parts. 
A

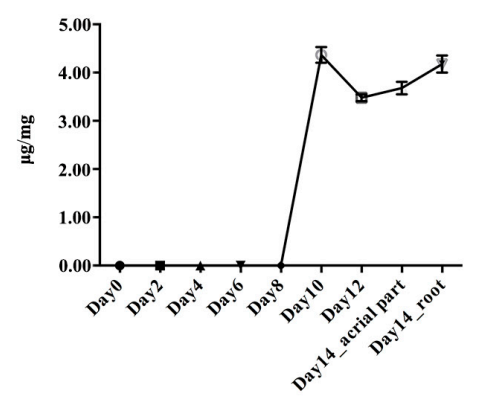

D

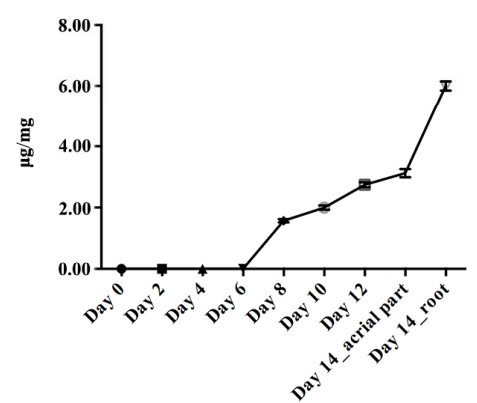

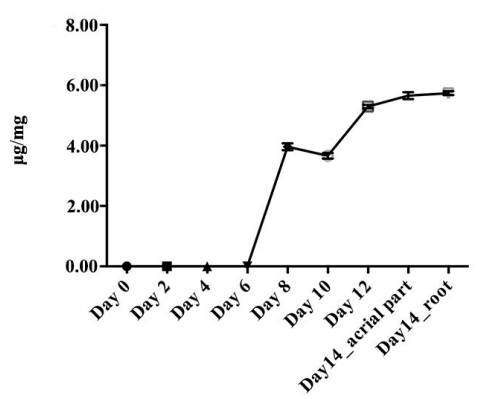

$\mathbf{E}$

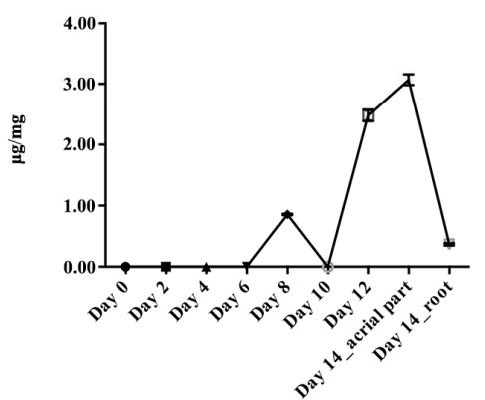

C

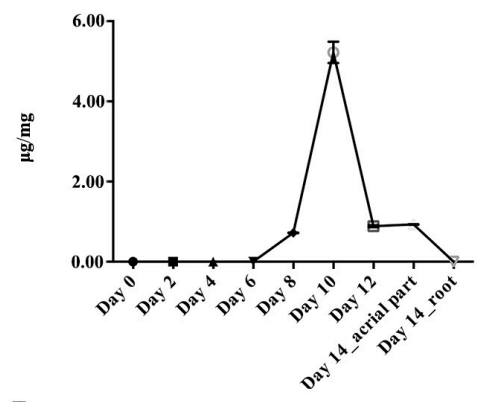

$\mathbf{F}$

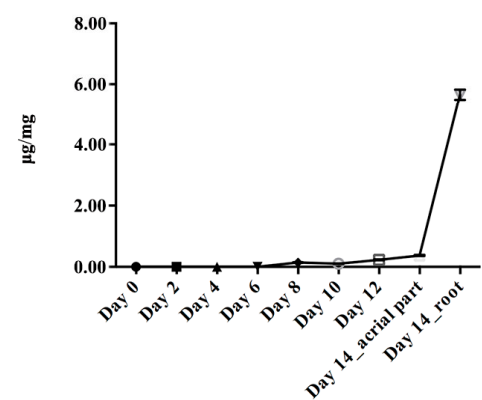

Figure 4. The accumulation patterns of flavonoids in S. baicalensis from seed germination to the true leaves coming out. (A): Isocarthamidin-7-O- $\beta$-D-glucuronide; (B): Scutellarin; (C): Apigenin-7-O$\beta$-D-glucuronide; (D): Baicalin; (E): Chrysin-7-O- $\beta$-D-glucuronide; (F): Wogonoside; The units " $\mu \mathrm{g} / \mathrm{mg}$ " meant the contents of analytes in per mg of freeze-dried samples.

\subsection{The Accumulation Patterns of Main Flavonoids in Roots of S. baicalensis}

After the true leaves of S. baicalensis appeared (on the 14th day), the main flavonoids, such as baicalin, wogonoside and their aglycones, accumulated rapidly until to the full-bloom stage. However, with the growth and development of $S$. baicalensis, the contents of isocarthamidin-7-O- $\beta$-D-glucuronide, scutellarin, carthamidin-7-O- $\beta$-D-glucuronide, apigenin-7-O- $\beta$-D-glucuronide and chrysin-7-O- $\beta$-D-glucuronide in the root were too low to be detected. Therefore, these five flavonoid compounds were not quantified in the root of S. baicalensis. As shown in Figure 5, the content of baicalein in the root increased from the 14th day and reached its highest level $(14.35 \mu \mathrm{g} / \mathrm{mg})$ near the full-bloom stage. Then it decreased significantly. The accumulation pattern of wogonin in the root was similar way to that of baicalein. The content of wogonin in the root reached to the highest level $(5.23 \mu \mathrm{g} / \mathrm{mg})$ at the beginning of the reproductive stage (Table S2).

The contents of baicalin and wogonoside in the root accumulated rapidly from when the true leaves appeared. When near to the full-bloom stage, the contents of both baicalin and wogonoside reached their peak values, 277.90 and $84.47 \mu \mathrm{g} / \mathrm{mg}$, respectively. As baicalin and wogonoside were synthesized from baicalein and wogonin, respectively, when the reproductive organs began to develop, the contents of baicalein and wogonin in the root decreased. As there might not be sufficient aglycones synthesized at the reproductive growth stage, the contents of baicalin and wogonoside stopped increasing and changed on a small scale after the full-bloom stage. The logistic curve and Gompertz curve are commonly used to interpret the progress of biological growth phenomena $[37,38]$. Both these growth models gave "S"-shaped curves. In the roots of S. baicalensis, the baicalin and wogonoside accumulated rapidly in a short time at the initial stage (Figure 5). After that, their contents stopped increasing and fluctuated in a narrow range. The accumulation patterns of baicalin and wogonoside were like "S" curves, so the logistic growth curve and the Gompertz growth curve were used to fit the accumulation patterns of baicalin and wogonoside. Raw data of the contents were transformed into their logarithmic values and also were used to fit the models. As shown in Table 3 and Figure 6, 
the models matched with the translated data had bigger determination coefficient $\left(\mathrm{R}^{2}\right)$ and smaller sum of squares due to error (SSE) values than those models matched with the raw data. The logistic equation fitted by the translated data showed bigger $\mathrm{R}^{2}$ and smaller SSE than the Gompertz equation, indicating that the logistic growth model fitted the accumulation patterns of baicalin and wogonoside in the root of S. baicalensis well. Through the models, the contents of baicalin and wogonoside could be predicted, so these models could be used to guide scientific cultivation of $S$. baicalensis and to predict the optimum harvest stage. In general, the main bioactive ingredients enriched rapidly before the full-bloom stage and then changed to a small extent.

A

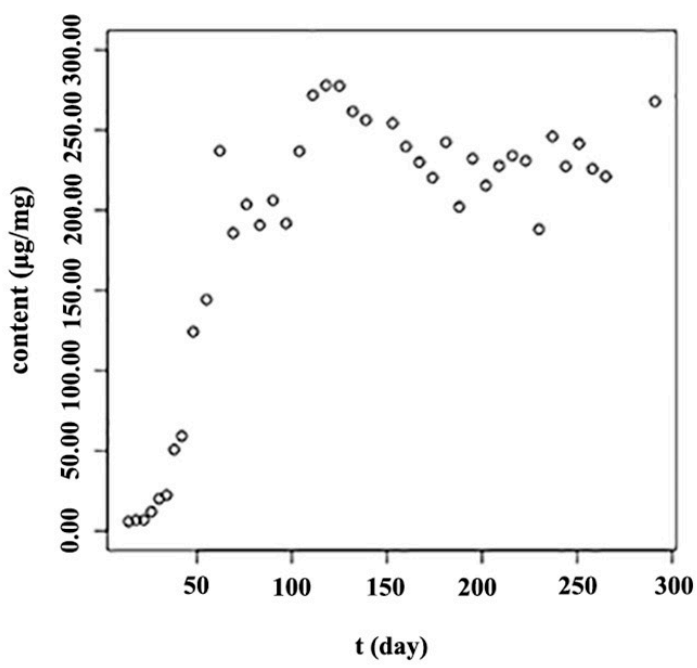

C

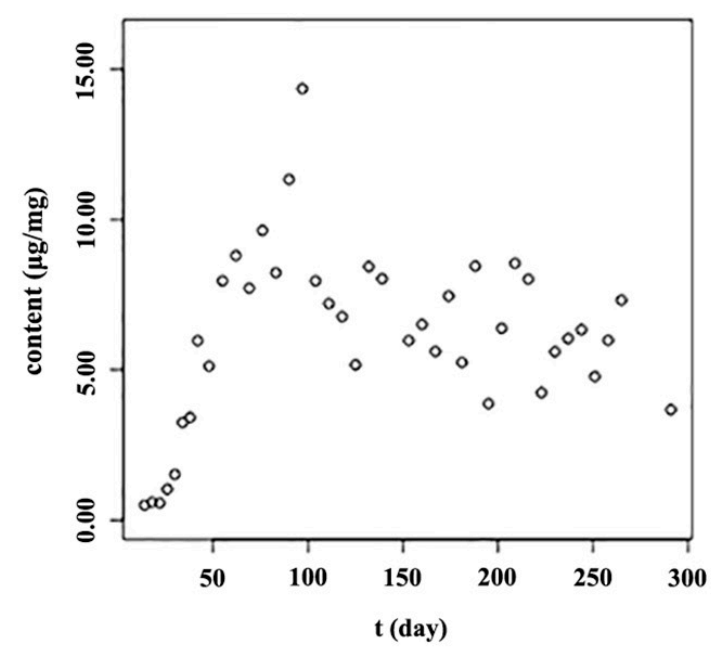

B

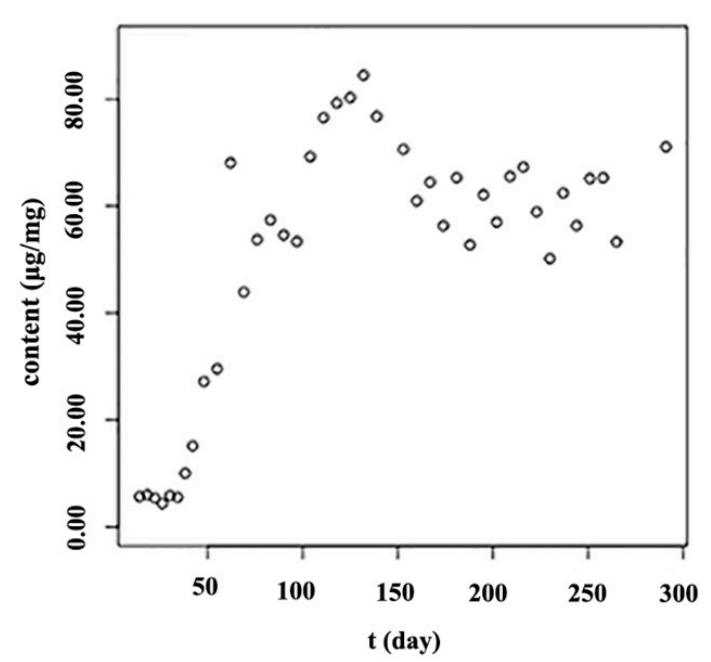

D

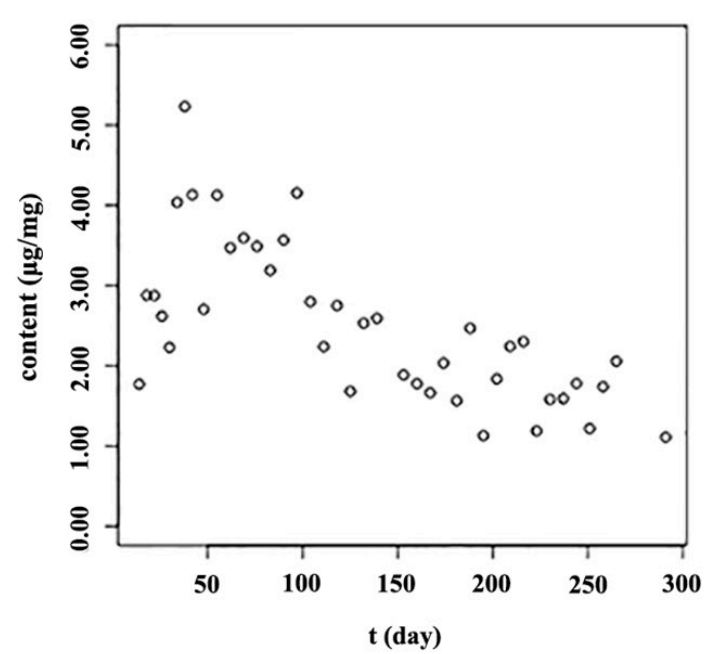

Figure 5. Accumulation patterns of main flavonoids in the root of S. baicalensis. (A): Baicalin; (B): Wogonoside; (C): Baicalein; (D): Wogonin; The units " $\mu \mathrm{g} / \mathrm{mg}$ " meant the contents of analytes in per mg of freezedried samples. 
Table 3. Growth models for the accumulation of baicalin and wogonoside in root of S.baicalensis.

\begin{tabular}{lccccccc}
\hline \multirow{2}{*}{ Model } & \multirow{2}{*}{ Equation } & \multirow{2}{*}{ Chem } & \multicolumn{5}{c}{ Parameter Values } \\
\cline { 4 - 7 } & & & $\mathbf{a}$ & $\mathbf{b}$ & $\mathbf{c}$ & $\mathbf{R}^{2}$ & SSE \\
\hline \multirow{3}{*}{ Gompertz } & $\mathrm{Y}=\mathrm{a} \times \exp [-\exp (\mathrm{b}-\mathrm{c} \times \mathrm{t})]$ & Baicalin & 235.492 & 3.303 & 0.076 & 0.936 & $19,527.371$ \\
& & Baicalin * & 5.485 & 1.172 & 0.058 & 0.977 & 1.172 \\
& & Wogonoside & 67.777 & 3.246 & 0.07 & 0.877 & 2928.026 \\
& & Wogonoside * & 4.205 & 0.896 & 0.043 & 0.923 & 2.609 \\
\hline \multirow{2}{*}{ Logistic } & $\mathrm{Y}=\mathrm{a} /[1+\mathrm{b} \times \exp (-\mathrm{c} \times \mathrm{t})]]$ & Baicalin & 233.686 & 366.795 & 0.12 & 0.933 & $20,164.7$ \\
& & Wogonoside & 5.468 & 8.437 & 0.078 & 0.984 & 0.816 \\
& & Wogonoside * $^{*}$ & 4.189 & 5.864 & 0.058 & 0.938 & 2.102 \\
\hline
\end{tabular}

Y meant the contents of the quantified compound and $t$ means the growth time of S. baicalensis. ${ }^{*}$ The raw data of contents were translated by taking logarithm.
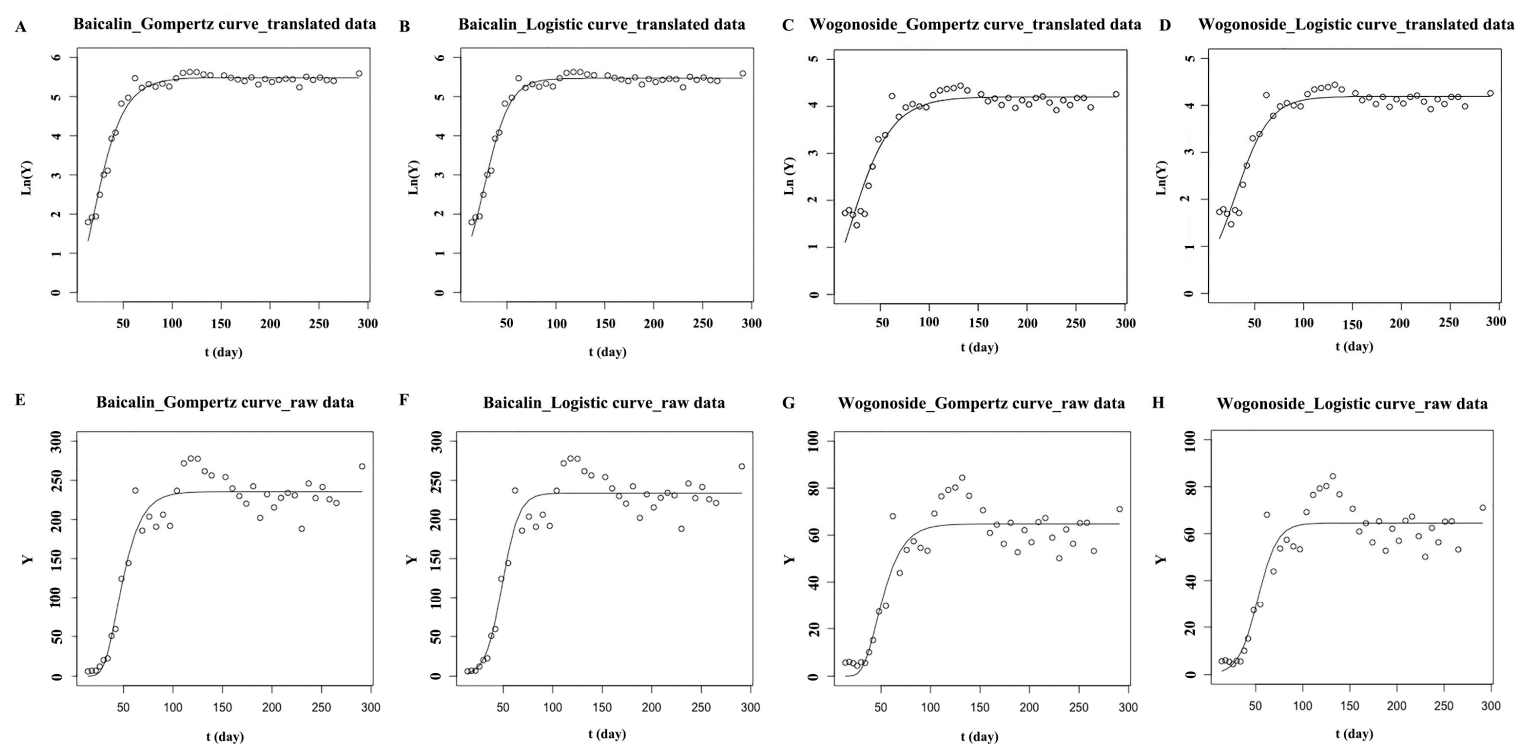

Figure 6. The growth curves fitting for baicalin and wogonoside in root of S. baicalensis. (A,C): the Gompertz growth curves fitted by the translated data of the content of baicalin and wogonoside; (B,D): the Logistic growth curves fitted by the translated data of the content of baicalin and wogonoside; (E,G): the Gompertz growths curve fitted by the raw data of the content of baicalin and wogonoside; $(\mathbf{F}, \mathbf{H})$ : the Logistic growth curves fitted by the raw data of the content of baicalin and wogonoside; Y meant the contents of the quantified compounds in freeze-dried samples; $\operatorname{Ln}(\mathrm{Y})$ meant that the raw data of contents were translated by taking logarithm.

\subsection{Dynamic Accumulation of Flavonoids in Stems and Leaves of S. baicalensis at Different Growth Stages}

As the results in Figures 7 and 8 and Table S2 indicate, the five main flavonoids-isocarthamidin-7$O-\beta$-D-glucuronide, scutellarin, carthamidin-7-O- $\beta$-D-glucuronide, apigenin-7-O- $\beta$-D-glucuronide and baicalin - had similar accumulation patterns in the stems and leaves of $S$. baicalensis. The main flavonoids accumulated rapidly after the true leaves appeared. As flavonoids play an important role in UV protection [39,40], they are often presented in the epidermal cell layers of the leaf and in the stem tissues which were susceptible to UV light to protect them from photo-oxidative damage [41]. The reproductive stage (from day 69 to day 167) ranges from June to August. During the reproductive stage, the sunshine duration is the longest and the illumination intensity reached its highest value, so the contents of flavonoids also reach to their highest levels from June to August. However, during the full bloom stage (approximately from day 90 to day 111), the contents of flavonoids in the stems and leaves decreased to some extent. This might be due to the fact that, at the full-bloom stage, flavonoids might be mainly synthesized for 
reproductive growth and the syntheses of flavonoids in vegetative organs might be depressed, so the contents of flavonoids in stems and leaves decreased to some extent during the full-bloom stage. Therefore, the accumulation patterns of main flavonoids in stems and leaves of $S$. baicalensis showed an " $\mathrm{M}$ " shape. Based on the results, the optimum harvest time of stems and leaves are the initial or later phases of the reproductive stage.

A

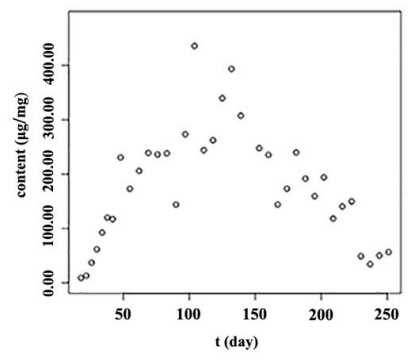

C

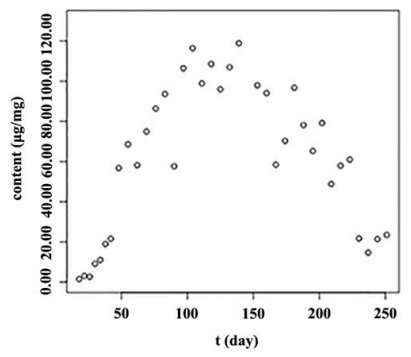

D

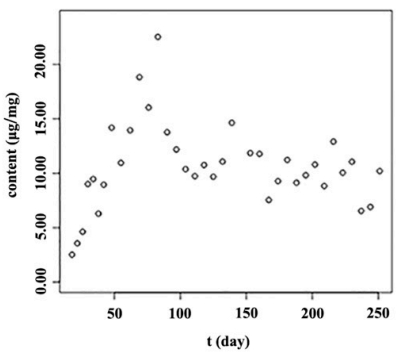

B

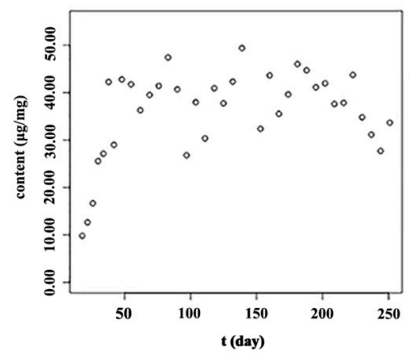

$\mathbf{E}$

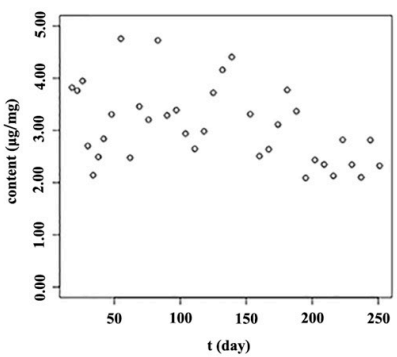

Figure 7. Accumulation patterns of main flavonoids in the leaf of S. baicalensis. (A): Isocarthamidin-7-O- $\beta$-Dglucuronide; (B): Scutellarin; (C): Carthamidin-7-O- $\beta$-D-glucuronide; (D): Apigenin-7-O- $\beta$-D-glucuronide; (E): Baicalin; The units " $\mu \mathrm{g} / \mathrm{mg}^{\prime}$ meant the contents of analytes in per mg of freeze-dried samples.

A

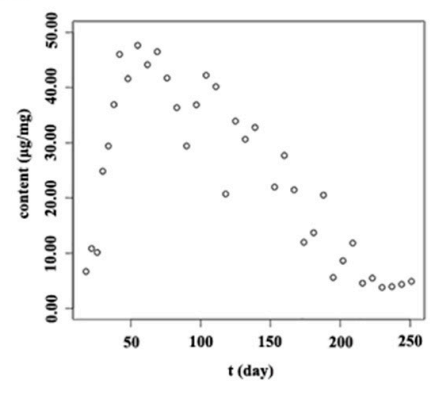

C

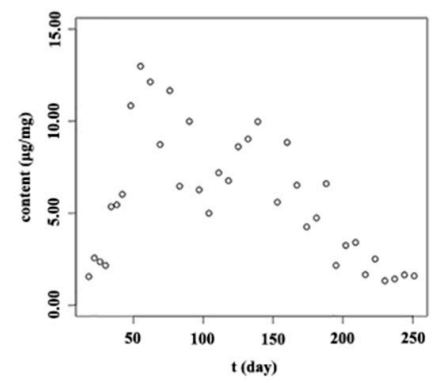

B

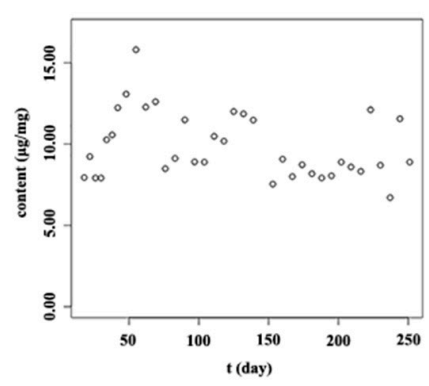

$\mathbf{E}$
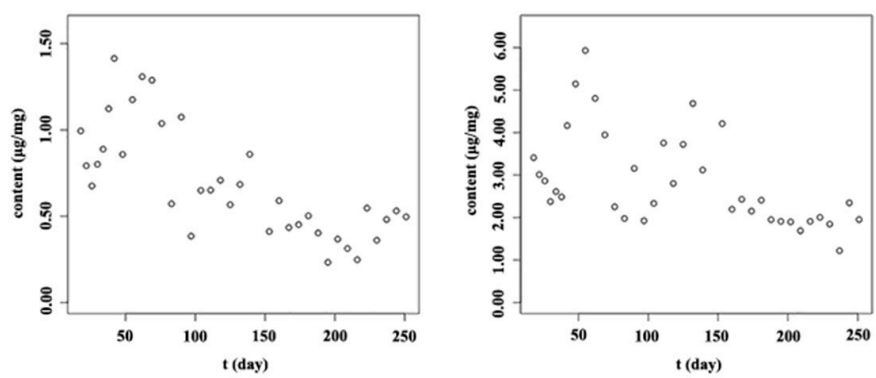

Figure 8. Accumulation patterns of main flavonoids in the stem of S. baicalensis. (A): Isocarthamidin-7-O- $\beta$ D-glucuronide; (B): Scutellarin; (C): Carthamidin-7-O- $\beta$-D-glucuronide; (D): Apigenin-7-O- $\beta$-D-glucuronide; (E): Baicalin; The units " $\mu \mathrm{g} / \mathrm{mg}$ " meant the contents of analytes in per $\mathrm{mg}$ of freeze-dried samples. 


\subsection{Dynamic Accumulation of Flavonoids in Reproductive Organs of S. baicalensis at Different Growth Stages}

The morphological characteristics of the reproductive organs changed with their growth and development. Accompanying the changes in morphological characteristics, the contents of chemical components in the reproductive organs also changed significantly [42,43]. Thus, the accumulation patterns of main flavonoids in the reproductive organs of $S$. baicalensis, isocarthamidin-7-O- $\beta$-D-glucuronide, scutellarin, carthamidin-7-O- $\beta$-D-glucuronide, apigenin-7-O- $\beta$-D-glucuronide, baicalin and chrysin-7-O- $\beta$-Dglucuronide were detected. As the results shown in Figure 9 and Table S2, with the morphological changes, the contents of the main flavonoids in reproductive organs changed significantly during the six different development stages. The contents of main flavonoids reached to their highest levels in FB1, except for apigenin-7-O- $\beta$-D-glucuronide and baicalin. The contents of isocarthamidin-7-O- $\beta$-D-glucuronide and carthamidin-7-O- $\beta$-D-glucuronide reached to their peak values at the initial development stage of the flower buds, and then decreased to their lowest levels during flowering. After that, the contents of these two compounds increased slightly. In flavonoids metabolic pathway, flavanone was the precursor substance of anthocyanin. When flowering, the common precursors might be used to synthesize anthocyanin. This might explain why the contents of isocarthamidin-7-O- $\beta$-D-glucuronide and carthamidin-7-O- $\beta$-D-glucuronide decreased with the flower bud growth.

A

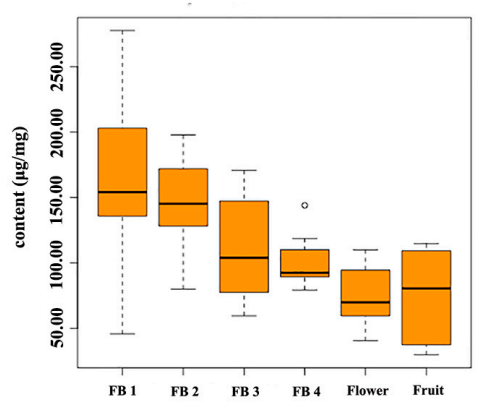

D

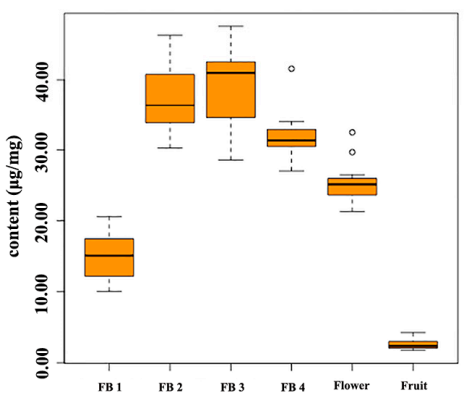

B

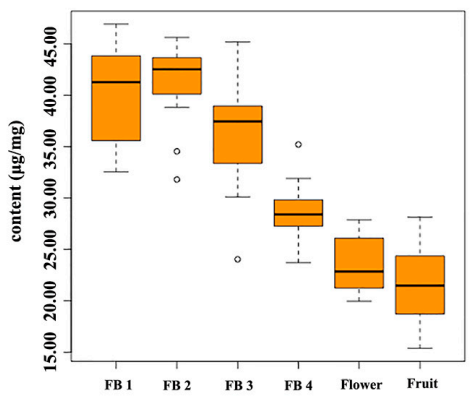

$\mathbf{E}$

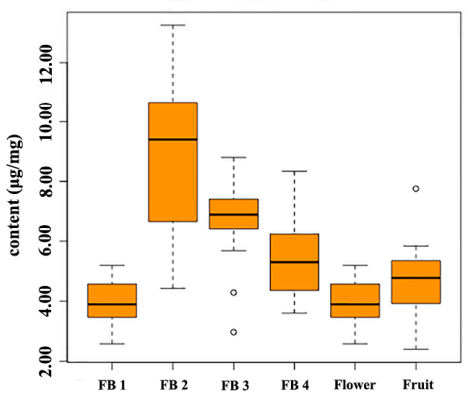

C

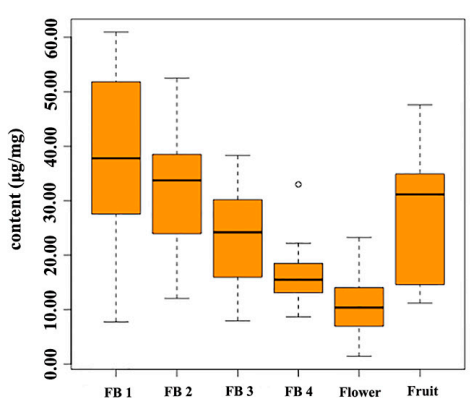

$\mathbf{F}$

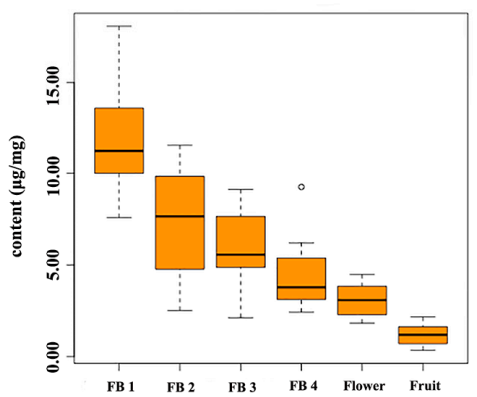

Figure 9. The accumulation patterns of main flavonoids in reproductive organs of $S$. baicalensis. (A): Isocarthamidin-7-O- $\beta$-D-glucuronide; (B): Scutellarin; (C): Carthamidin-7-O- $\beta$-D-glucuronide; (D): Apigenin-7-O- $\beta$-D-glucuronide; (E): Baicalin; (D): Chrysin-7-O- $\beta$-D-glucuronide; The units " $\mu \mathrm{g} / \mathrm{mg}$ " meant the contents of analytes in per mg of freeze-dried samples. Each "o" meant the content of the analyte in a sample which was bigger than the $75 \%$ quantile plus one and a half times of the box length or smaller than the $25 \%$ quantile minus one and a half of times of the box length. The box length was the $75 \%$ quantile of the content of the analyte in a sample minus the $25 \%$ quantile.

The contents of scutellarin and chrysin-7-O- $\beta$-D-glucuronide decreased continuously during the reproductive organ growth (from FB1 to Fruit). The contents of apigenin-7-O- $\beta$-D-glucuronide increased from FB1 to FB3, then decreased to the lowest level at fruiting. The content of baicalin reached a peak value in FB2 and then decreased to the lowest level when flowering. At the initial flower bud development stage, anthocyanins in the reproductive organs might be not enough to defend 
against UV damage, so flavones were synthesized to absorb UV [44,45]. As anthocyanins and flavone are synthesized in the same pathway, they share the same precursor substances. Therefore, with the flower bud growth, anthocyanins were synthesized continuously and the synthesis of flavones such as apigenin-7-O- $\beta$-D-glucuronide, chrysin-7-O- $\beta$-D-glucuronide, scutellarin, baicalin was depressed. In conclusion, the flower budding stages of $S$. baicalensis might be a more optimal time to harvest than the flower and fruit stage when using for medicinal properties and the flower buds could be separated into different grades by length.

\section{Materials and Methods}

\subsection{Plant Materials and Sample Preparation}

The seeds of S. baicalensis were collected from Kushan County (Rizhao, China) and planted in the Medicinal Botanics Garden of China Pharmaceutical University (Nanjing, China) in March of 2016. From seed cultivation (day 0) to seedling growth without true leaves (day 12), the whole plants were harvested every 2 days. From the 14th day (day 14) to the 42th day (day 42), the samples were harvested every 4 days. After day 42, the samples were collected every 7 days until the 251th day (day 251). The samples were collected from the beginning of seed cultivation until the aerial parts died. After the first pair of true leaves appeared (day 14), the whole plant was separated into different parts (such as root, stem, leaf, flower bud, flower and fruit). The flower buds were also divided into four stages by length which were flower bud 1 (FB1, $<0.5 \mathrm{~cm}$ ), flower bud 2 (FB2, $0.5-1 \mathrm{~cm}$ ), flower bud 3 (FB3, $1-1.5 \mathrm{~cm}$ ) and flower bud 4 (FB4, 1.5-2 cm). At each collection time, 10 plants were collected and pooled. All the collected fresh plant materials were flash frozen in liquid nitrogen. The frozen samples were quickly ground to a fine powder and freeze-dried, then stored in $-80^{\circ} \mathrm{C}$ until analyzed. The samples collected at day 0 , day 2 , day 4 , day 6 , day 8 , day 10 , day 12 , day 14 , day 18 , day 22 , day 62 and day 83 were used for qualitative analysis. All the samples collected as mentioned above from day 0 to day 251 were used for quantitative analysis. For quantitative analysis, each freeze-dried mixed sample (from day 0 to day 251) was performed in triplicate, and triplicate samples were extracted, respectively. The accurately weighed freeze-dried powder $(5 \mathrm{mg})$ was suspended in $70 \%$ methanol $(v / v, 1 \mathrm{~mL})$, sonicated for $30 \mathrm{~min}$, and then cooled to room temperature. After centrifugation at 12,000 $\mathrm{g}$ for $10 \mathrm{~min}$, the supernatant was transferred to a $2 \mathrm{~mL}$ volumetric flask. This step was repeated one time and then the volume was adjusted to the calibration mark with $70 \%$ methanol $(v / v)[6]$. The supernatant solution was filtered through a $0.22 \mu \mathrm{m}$ filter before analysis.

\subsection{Chemicals and Reagents}

The reference standards, isocarthamidin-7-O- $\beta$-glucuronide and carthamidin-7-O- $\beta$-Dglucuronide, were isolated in our laboratory. Baicalin, baicalein, wogonoside, wogonin, apigenin-7-O- $\beta$ D-glucuronide, chrysin-7-O- $\beta$-D-glucuronide, and scutellarin samples were purchased from Chengdu Mansite Biological Technology Co. (Chengdu, China). The purity of each compound was determined to be over $98 \%$ by HPLC analysis. Chromatography grade acetonitrile was purchased from Merck (Darmstadt, Germany). Ultrapure water for chromatography was obtained from an ULUP-II-20T purification system (ULUP, Nanjing, China). All other reagents were of analytical grade and purchased from Nanjing Chemical Regents Co. Ltd. (Nanjing, China).

\subsection{UHPLC-QTOF-MS/MS Based Qualitative Analysis and HPLC Quantification}

Chromatographic separation was performed on a Shimadzu LC-30A Series UHPLC system (Shimadzu, Duisburg, Germany). An ultimate HPLC XB-C18 column $(150 \mathrm{~mm} \times 2.1 \mathrm{~mm}, 3 \mu \mathrm{m}$, Welch, Shanghai, China) was applied for all analyses at $30{ }^{\circ} \mathrm{C}$. The mobile phase was a mixture of $0.1 \%$ formic acid-water (A) and $0.1 \%$ formic acid-acetonitrile (B) at a flow rate of $0.3 \mathrm{~mL} / \mathrm{min}$. The gradient condition was as follows: $0-6 \mathrm{~min}, 13 \% \mathrm{~B} ; 6-8 \mathrm{~min}, 13 \% \mathrm{~B} \rightarrow 18 \% \mathrm{~B} ; 8-14 \mathrm{~min}$, $18 \%$; $14-15 \mathrm{~min}, 18 \% \mathrm{~B} \rightarrow 23 \% \mathrm{~B}$; $15-22 \mathrm{~min}, 23 \% \mathrm{~B} ; 22-24 \mathrm{~min}, 23 \% \mathrm{~B} \rightarrow 25 \%$ B; $24-32 \mathrm{~min}, 25 \%$ B; 
32-34 min, 25\% B $\rightarrow 35 \%$ B; 34-39 min, 35\% B; 39-42 $\mathrm{min}, 35 \% \mathrm{~B} \rightarrow 40 \% \mathrm{~B} ; 42-47 \mathrm{~min}, 40 \% \mathrm{~B} ; 47-50 \mathrm{~min}$, $40 \% \mathrm{~B} \rightarrow 95 \% \mathrm{~B} ; 50-55 \mathrm{~min}, 95 \% \mathrm{~B} ; 55-56 \mathrm{~min} 95 \% \mathrm{~B}-13 \% \mathrm{~B}$, followed by 1 min of re-equilibration. The injection volume was $4 \mu \mathrm{L}$.

Mass spectrometry experiments were accomplished on an AB SCIEX Triple TOF ${ }^{\mathrm{TM}} 5600+$ system (AB SCIEX Technologies, Redwood City, CA, USA) equipped with an electrospray ionization (ESI) source. Samples were analyzed in negative ion modes to provide information for structural identification. The parameters were as follows: mass range, $m / z 100$ to 1000 ; electrospray ionization temperature $\left({ }^{\circ} \mathrm{C}\right): 500$; nebulizer gas pressure (psi): 60; ion spray voltage (KV): 4.5; collision energies (V): 40.

Each sample was quantified for 9 standard substances (Figure 10) using high performance liquid chromatography (HPLC) on an Agilent Series 1260 LC instrument (Agilent Technologies, Cambridge, MA, USA). The chromatographic condition was same as above mentioned and the detection wavelength was at $278 \mathrm{~nm}$ [46]. Standard stock solutions of the nine standard substances were prepared and then diluted to appropriate concentrations for calibration and method validation.

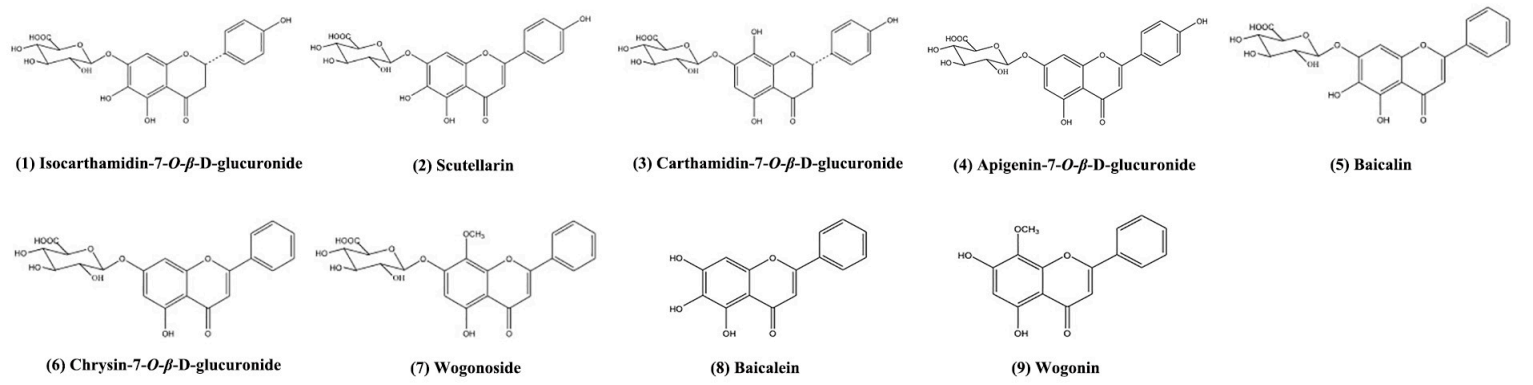

Figure 10. Structures of the quantified compounds. (1): Isocarthamidin-7-O- $\beta$-D-glucuronide; (2) Scutellarin; (3): Carthamidin-7-O- $\beta$-D-glucuronide; (4): apigenin-7-O- $\beta$-D-glucuronide; (5): Baicalin; (6): chrysin-7-O$\beta$-D-glucuronide; (7): Wogonoside; (8): Baicalein; (9): Wogonin.

\subsection{Method Validation}

Analyses of linear regression curve, limit of detection (LOD), limit of quantification (LOQ), repeatability, intra-day and inter-day stability as well as recovery for each standard substance were performed. The mixed standard solution was diluted with methanol to yield a series of standard solutions at appropriate concentrations to construct the calibration curves. LOD and LOQ were determined with signal-to-noise $(\mathrm{S} / \mathrm{N})$ ratios of 3 and 10 respectively.

To evaluate the precision, we analyzed the standard solutions with six replicates, three replicates for intra-day variability and three ones for inter-day variability. The RSD of each standard compounds was calculated. To confirm the repeatability, six different sample solutions were prepared from the same samples (the root which was collected in the 180th day and flower which was collected in the 139th day) were analyzed and variations were expressed by RSD. The stability was evaluated by storing the sample solutions (root which was collected in the 180th day and flower bud 3 which was collected in the 139th day) at $25^{\circ} \mathrm{C}$, then analyzed at $0 \mathrm{~h}, 2 \mathrm{~h}, 4 \mathrm{~h}, 6 \mathrm{~h}, 8 \mathrm{~h}, 12 \mathrm{~h}, 24 \mathrm{~h}, 48 \mathrm{~h}$ and $72 \mathrm{~h}$ respectively. As for the recovery validation, six duplicates of root (collected in the 180th day) were added with certain amounts of standard compounds (baicalin, baicalein, wogonoside and wogonin) for extraction and recovery assessment. Six duplicates of flower bud 3 (collected at the 139th day) were added with certain amounts of standard compounds (isocarthamidin-7-O- $\beta$-D-glucuronide, scutellarin, carthamidin-7-O- $\beta$-D-glucuronide, apigenin-7-O- $\beta$-D-glucuronide, chrysin-7- $O$ - $\beta$-D-glucuronide) for extraction and recovery assessment.

\subsection{Data Analysis}

The raw data from the UPLC-QTOF-MS/MS were qualitatively analyzed by Peakview Software (version1.2.0.3, AB SCIEX, Redwood City, CA, USA). In quantitative analysis, each sample was 
performed in triplicate, and the data were presented as the mean value \pm standard deviation (SD). The units " $\mu \mathrm{g} / \mathrm{mg}$ " meant the contents of analytes in per mg of freeze-dried samples.

Gompertz curve and Logistic curve were adopted to describe the relationship between flavonoid contents and growing time. The results were fitted to the models as follows (Equation (1)):

$$
\begin{aligned}
& \text { The Gompertz curve: } \mathrm{Y}=\mathrm{a} \times \exp [-\exp (\mathrm{b}-\mathrm{c} \times \mathrm{x})] \\
& \text { The logistic curve: } \mathrm{Y}=\mathrm{a} /[1+\mathrm{b} \times \exp (-\mathrm{c} \times \mathrm{x})]
\end{aligned}
$$

where $\mathrm{Y}$ represented the contents of baicalin or wogonoside. The $\mathrm{x}$ was the time after seed cultivation. The $a, b$, and c were three arbitrary constans, which correspond essentially to the upper asymptote, the time origin, and the time unit [37]. Nonlinear regression analysis was performed in IBM SPSS Statistics 23 (IBM, New York, NY, USA). The other data analysis and their visualization were processed in the software $\mathrm{R}$ (version 3.2.4, a language and environment for statistical computing. R Foundation for Statistical Computing, Vienna, Austria.).

\section{Conclusions}

In this study, the metabolic profiles of $S$. baicalensis at different growth stages were characterized by UHPLC-QTOF-MS/MS and HPLC-DAD. The metabolic profiles and quantitative analysis revealed that the chemical compositions in seeds and seedlings were very different from that in mature plants of $S$. baicalensis and there was clear chemical specificity among different organs. At the initial seed germination stage, S. baicalensis mainly contained flavonols. With further growth and development, the flavonoids, considered the main bioactive compounds in S. baicalensis, were synthesized and accumulated. The study also provided an effective reference for the optimal harvest time according to the dynamic accumulation patterns of target components. It is recommended that the optimal harvest time for the aerial parts of $S$. baicalensis is at the initial stage of reproductive growth and the flower buds should be harvested before flowering for better quality of their medicinal resources. Our study could effectively promote the scientific cultivation and rational utilization of $S$. baicalensis.

Supplementary Materials: The following are available online. Figure S1: The structures of the identified compounds; Table S1: The method validation results; Table S2: The contents of quantified compounds in the roots, stems, leaves of S. baicalensis; Table S3: The contents of quantified compounds in the reproductive organs of S. baicalensis.

Acknowledgments: This work was financially supported by the Public Welfare Industry Research Project for "Study on the rational utilization of the resources of aquatic and salt-tolerant Chinese medicine" (Grant no. 201407002).

Author Contributions: M.Q. and J.X. conceived and designed experiments. J.X., Y.Y., and R.S. carried out experiments and collected data. J.X., G.W., G.X. and Y.Z. analyzed and interpreted data. M.Q. and J.X. drafted and edited the manuscript. All authors were involved in writing the paper and had final approval of the submitted and published versions.

Conflicts of Interest: The authors declare no conflict of interest.

\section{References}

1. Chinese Pharmacopoeia Commission. Pharmacopoeia of the People's Republic of China; Chinese Medical Science and Technology Press: Beijing, China, 2015; Volume 1, pp. 301-302.

2. Shang, X.F.; He, X.R.; He, X.Y.; Li, M.X.; Zhang, R.X.; Fan, P.C.; Zhang, Q.L.; Jia, Z.P. The genus Scutellaria an ethnopharmacological and phytochemical review. J. Ethnopharmacol. 2010, 128, 279-313. [CrossRef] [PubMed]

3. Saralamma, V.V.G.; Lee, H.J.; Hong, G.E.; Park, H.S.; Yumnam, S.; Raha, S.; Lee, W.S.; Kim, E.H.; Sung, N.J.; Lee, S.J.; et al. Korean Scutellaria baicalensis Georgi flavonoid extract induces mitochondrially mediated apoptosis in human gastric cancer AGS cells. Oncol. Lett. 2017, 14, 607-614. [CrossRef] [PubMed]

4. Pan, T.L.; Wang, P.W.; Leu, Y.L.; Wu, T.H.; Wu, T.S. Inhibitory effects of Scutellaria baicalensis extract on hepatic stellate cells through inducing G2/M cell cycle arrest and activating ERK-dependent apoptosis via Bax and caspase pathway. J. Ethnopharmacol. 2012, 139, 829-837. [CrossRef] [PubMed] 
5. Shan, B.; Cai, Y.Z.; Brooks, J.D.; Corke, H. The in vitro antibacterial activity of dietary spice and medicinal herb extracts. Int. J. Food Microbiol. 2007, 117, 112-119. [CrossRef] [PubMed]

6. Qiao, X.; Li, R.; Song, W.; Miao, W.J.; Liu, J.; Chen, H.B.; Guo, D.A.; Ye, M. A targeted strategy to analyze untargeted mass spectral data: Rapid chemical profiling of Scutellaria baicalensis using ultra-high performance liquid chromatography coupled with hybrid quadrupole orbitrap mass spectrometry and key ion filtering. J. Chromatogr. A 2016, 1441, 83-95. [CrossRef] [PubMed]

7. Seo, O.N.; Kim, G.S.; Kim, Y.H.; Park, S.; Jeong, S.W.; Lee, S.J.; Jin, J.S.; Sung, C.S. Determination of polyphenol components of Korean Scutellaria baicalensis Georgi using liquid chromatography-tandem mass spectrometry: Contribution to overall antioxidant activity. J. Funct. Foods 2013, 5, 1741-1750. [CrossRef]

8. Zhao, T.H.; Chen, S.P.; Yang, H.S.; Deng, S.H. Antiviral effects of active fraction from stems and leaves of Scutellaria baicalensis. J. China Pharm. Univ. 2006, 37, 544-547.

9. Li, S.T.; Yang, H.M.; Shi, Y.H.; Gong, M.Y. Protective effects of Scutellaria baicalensis stem-leaf total flavonoid on carbon tetrachloride acute hepatic injury in mice. J. Chengde Med. Coll. 2003, 20, 292-294.

10. Gao, Z.; Huang, K.; Xu, H. Protective effects of flavonoids in the roots of Scutellaria baicalensis Georgi against hydrogen peroxide-induced oxidative stress in HS-SY5Y cells. Pharmacol. Res. 2001, 43, 173-178. [CrossRef] [PubMed]

11. Kong, X.Y.; Zhao, S.M. Protective effects of preconditioning of total fiavonoid from the stem and leaf of Scutellaria baicalensis on cardiocyte ultrastructure of rats with ischemic reperfusion. Chin. J. Clin. Rehabil. 2006, 10, 49-51.

12. Liu, G.; Rajesh, N.; Wang, X.; Zhang, M.; Wu, Q.; Li, S.; Chen, B.; Yao, S. Identification of flavonoids in the stems and leaves of Scutellaria baicalensis Georgi. J. Chromatogr. B Anal. Technol. Biomed. Life Sci. 2011, 879, 1023-1028. [CrossRef] [PubMed]

13. Wang, Z.; Yu, J.; Wu, J.; Qi, F.; Wang, H.; Wang, Z.; Xu, Z. Scutellarin protects cardiomyocyte ischemia-reperfusion injury by reducing apoptosis and oxidative stress. Life Sci. 2016, 157, 200-207. [CrossRef] [PubMed]

14. Ma, Q.; Zhang, X.-M.; Jiang, J.-G.; Zhu, W. Apigenin-7-O- $\beta$-D-glucuronide inhibits modified low-density lipoprotein uptake and foam cell formation in macrophages. J. Funct. Foods 2017, 36, 615-621. [CrossRef]

15. Wang, H.; Cao, J.; Xu, S.; Gu, D.; Wang, Y.; Xiao, S. Depletion of high-abundance flavonoids by metal complexation and identification of low-abundance flavonoids in Scutellaria baicalensis Georgi. J. Chromatogr. A 2013, 1315, 107-117. [CrossRef] [PubMed]

16. Moco, S.; Capanoglu, E.; Tikunov, Y.; Bino, R.J.; Boyacioglu, D.; Hall, R.D.; Vervoort, J.; Devos, R.C. Tissue specialization at the metabolite level is perceived during the development of tomato fruit. J. Exp. Bot. 2007, 58, 4131-4146. [CrossRef] [PubMed]

17. Abu-Reidah, I.M.; Del, M.C.M.; Arráez-Román, D.; Fernández-Gutiérrez, A.; Segura-Carretero, A. UHPLCESI-QTOF-MS-based metabolic profiling of Vicia faba L. (Fabaceae) seeds as a key strategy for characterization in foodomics. Electrophoresis 2014, 35, 1571-1581. [CrossRef] [PubMed]

18. Álvarezfernández, M.A.; Hornedoortega, R.; Cerezo, A.B.; Troncoso, A.M.; García-Parrilla, M.C. Determination of nonanthocyanin phenolic compounds using High-Resolution Mass Spectrometry (UHPLC-Orbitrap- MS/MS) and impact of storage conditions in a beverage made from Strawberry by fermentation. J. Agric. Food Chem. 2016, 64, 1367-1376. [CrossRef] [PubMed]

19. Erşan, S.; Üstündağ, Ö.G.; Carle, R.; Schweiggert, R.M. Determination of pistachio (Pistacia vera L.) hull (exo- and mesocarp) phenolics by HPLC-DAD-ESI/MS n and UHPLC-DAD-ELSD after ultrasound-assisted extraction. J. Food Compos. Anal. 2017, 62, 103-114. [CrossRef]

20. Zhang, L.; Tu, Z.C.; Xie, X.; Wang, H.; Wang, H.; Wang, Z.X.; Sha, X.M.; Lu, Y. Jackfruit (Artocarpus heterophyllus Lam.) peel: A better source of antioxidants and $\alpha$-glucosidase inhibitors than pulp, flake and seed, and phytochemical profile by HPLC-QTOF-MS/MS. Food Chem. 2017, 234, 303-313. [CrossRef] [PubMed]

21. Wang, Y.; Johnson-Cicalese, J.; Singh, A.P.; Vorsa, N. Characterization and quantification of flavonoids and organic acids over fruit development in American cranberry (Vaccinium macrocarpon) cultivars using HPLC and APCI-MS/MS. Plant Sci. 2017, 262, 91-102. [CrossRef] [PubMed]

22. Huang, Y.L.; Shen, C.C.; Shen, Y.C.; Chiou, W.F.; Chen, C.C. Anti-inflammatory and antiosteoporosis flavonoids from the rhizomes of Helminthostachys zeylanica. J. Nat. Prod. 2017, 80, 246-253. [CrossRef] [PubMed]

23. Guo, Y.; Chen, X.; Qi, J.; Yu, B. Simultaneous qualitative and quantitative analysis of flavonoids and alkaloids from the leaves of Nelumbo nucifera Gaertn. using high-performanceliquid chromatography with quadrupole time-of-flight mass spectrometry. J. Sep. Sci. 2016, 39, 2499-2507. [CrossRef] [PubMed] 
24. He, L.; Zhang, Z.; Lu, L.; Liu, Y.; Li, S.; Wang, J.; Song, Z.; Yan, Z.; Miao, J. Rapid identification and quantitative analysis of the chemical constituents in Scutellaria indica L. by UHPLC-QTOF-MS and UHPLC-MS/MS. J. Pharm. Biomed. Anal. 2016, 117, 125-139. [CrossRef] [PubMed]

25. Zhang, Z.; He, L.; Lu, L.; Liu, Y.; Dong, G.; Miao, J.; Luo, P. Characterization and quantification of the chemical compositions of Scutellariae barbatae herba and differentiation from its substitute by combining UHPLC-PDA-QTOF-MS/MS with UHPLC-MS/MS. J. Pharm. Biomed. Anal. 2015, 109, 62-66. [CrossRef] [PubMed]

26. Lin, W.; Liu, S.; Wu, B. Structural identification of chemical constituents from Scutellaria baicalensis by HPLC-ESI-MS/MS and NMR spectroscopy. Asian J. Chem. 2013, 25, 3799-3805. [CrossRef]

27. Liu, G.; Ma, J.; Chen, Y.; Tian, Q.; Shen, Y.; Wang, X.; Chen, B.; Yao, S. Investigation of flavonoid profile of Scutellaria bacalensis Georgi by high performance liquid chromatography with diode array detection and electrospray ion trap mass spectrometry. J. Chromatogr. A 2009, 1216, 4809-4814. [CrossRef] [PubMed]

28. Yukinori, M.; Yoshitaka, I.; Hiroyuki, S.; Tsuyoshi, T. Studies on the constituents of Seutellaria species (X) On the flavonoid constituents of the leaves of Scutellaria baicalensis Gergi. Shoyakugaku Zasshi 1988, 42, 216-219.

29. Wang, L.; Zhu, X.; Lou, X.; Zheng, F.; Feng, Y.; Liu, W.; Feng, F.; Xie, N. Systematic characterization and simultaneous quantification of the multiple components of Rhododendron dauricum based on high-performance liquid chromatography with quadrupole time-of-flight tandem mass spectrometry. J. Sep. Sci. 2015, 38, 3161-3169. [CrossRef] [PubMed]

30. Islam, M.N.; Downey, F.; Ng, K.Y. Comprehensive profiling of flavonoids in Scutellaria incana L. using LC-Q-TOF-MS. Acta Chromatogr. 2013, 25, 555-569. [CrossRef]

31. Zheng, L.; Cong, H.J.; Wu, B.; Xue, M.; Xiang, T.; Yao, Z.Q.; Lin, W.H. HPLC-Q-TOF-MS/MS Analysis of the Constituents in the Rat Biological Fluids After Oral Administration of Qing Ru Xiao granules. J. Chromatogr. Sci. 2015, 53, 1562-1569. [CrossRef] [PubMed]

32. Li, Z.P.; Wei, H.Q. An overview of the chemical constituents of Scutellaria. Drugs Clin. 1994, 9, 147-156.

33. Xi, Y.L.; Shang, Y.Z. Research progress of the leaf and stem of Scutellaria baicalensis. J. Chengde Med. Coll. 2007, 24, 293-295.

34. Pourcel, L.; Routaboul, J.M.; Kerhoas, L.; Caboche, M.; Lepiniec, L.; Debeaujon, I. TRANSPARENT TESTA10 encodes a laccase-like enzyme involved in oxidative polymerization of flavonoids in Arabidopsis seed coat. Plant Cell 2005, 17, 2966-2980. [CrossRef] [PubMed]

35. Auger, B.; Marnet, N.; Gautier, V.; Maia-Grondard, A.; Leprince, F.; Renard, M.; Guyot, S.; Nesi, N.; Routaboul, J.M. A Detailed Survey of Seed Coat Flavonoids in Developing Seeds of Brassica napus L. J. Agric. Food Chem. 2010, 58, 6246-6256. [CrossRef] [PubMed]

36. Zhao, Q.; Zhang, Y.; Wang, G.; Hill, L.; Weng, J.K.; Chen, X.Y.; Xue, H.; Martin, C. A specialized flavone biosynthetic pathway has evolved in the medicinal plant, Scutellaria baicalensis. Sci. Adv. 2016, 2, e1501780. [CrossRef] [PubMed]

37. Winsor, C.P. The gompertz curve as a growth curve. Proc. Natl. Acad. Sci. USA 1932, 18, 1-8. [CrossRef] [PubMed]

38. Li, X.H.; Li, Q.B.; Yang, T.W.; Nie, Z.N.; Chen, G.X.; Hu, L.Y. Responses of plant development, biomass and seed production of direct sown oilseed rape (Brassica napus) to nitrogen application at different stages in Yangtze River Basin. Field Crop. Res. 2016, 194, 12-20. [CrossRef]

39. Li, J.; Oulee, T.M.; Raba, R.; Amundson, R.G.; Last, R.L. Arabidopsis flavonoid mutants are hypersensitive to UV-B irradiation. Plant Cell 1993, 5, 171-179. [CrossRef] [PubMed]

40. Bieza, K.; Lois, R. An arabidopsis mutant tolerant to lethal Ultraviolet-B levels shows constitutively elevated accumulation of flavonoids and other phenolics. Plant Physiol. 2001, 126, 1105-1115. [CrossRef] [PubMed]

41. Winkel-Shirley, B. Biosynthesis of flavonoids and effects of stress. Curr. Opin. Plant Biol. 2002, 5, $218-223$. [CrossRef]

42. Wang, L.M.; Li, M.T.; Yan, Y.Y.; Ao, M.Z.; Wu, G.; Yu, L.J. Influence of flowering stage of Lonicera japonica thunb. on variation in volatiles and chlorogenic acid. J. Sci. Food Agric. 2009, 89, 953-957. [CrossRef]

43. Zhu, W.; Zheng, W.; Hu, X.; Xu, X.; Zhang, L.; Tian, J. Variations of metabolites and proteome in Lonicera japonica thunb. buds and flowers under UV radiation. Biochim. Biophys. Acta 2017, 1865, 404-413. [CrossRef] [PubMed]

44. Mierziak, J.; Kostyn, K.; Kulma, A. Flavonoids as important molecules of plant interactions with the environment. Molecules 2014, 19, 16240-16265. [CrossRef] [PubMed] 
45. Landi, M.; Tattini, M.; Gould, K.S. Multiple functional roles of anthocyanins in plant-environment interactions. Environ. Exp. Bot. 2015, 119, 4-17. [CrossRef]

46. Horvath, C.R.; Martos, P.A.; Saxena, P.K. Identification and quantification of eight flavones in root and shoot tissues of the medicinal plant huang-qin (Scutellaria baicalensis Georgi) using high-performance liquid chromatography with diode array and mass spectrometric detection. J. Chromatogr. A 2005, 1062, 199-207. [CrossRef] [PubMed]

Sample Availability: Samples of the compounds including isocarthamidin-7-O- $\beta$-D-glucuronide, scutellarin, carthamidin-7-O- $\beta$-D-glucuronide, apigenin-7-O- $\beta$-D-glucuronide, baicalin, chrysin-7-O- $\beta$-D-glucuronide, wogonoside, baicalein and wogonin are available from the authors.

(C) 2018 by the authors. Licensee MDPI, Basel, Switzerland. This article is an open access article distributed under the terms and conditions of the Creative Commons Attribution (CC BY) license (http:// creativecommons.org/licenses/by/4.0/). 